\title{
From Traditional Regional Analysis to Dynamics of Local Development: Foundations and Theoretical Reorientations
}

\author{
Charis Vlados \\ School of Business, University of Nicosia \\ E-mail: vlad.coop@gmail.com
}

Nikolaos Deniozos

Department of Turkish Studies and Modern Asian Studies, National and Kapodistrian University of Athens

Department of Economics, Democritus University of Thrace

E-mail: deniozos@gmail.com

\author{
Dimos Chatzinikolaou (Corresponding author) \\ Department of Economics, Democritus University of Thrace \\ E-mail: dimos.chatzinikolaou@gmail.com
}

\begin{abstract}
Agis Digkas
Department of Turkish Studies and Modern Asian Studies, National and Kapodistrian University of Athens

E-mail: agis.digkas@gmail.com
\end{abstract}

Received: January 10, 2019

Accepted: February 12, 2019

Published: March 27, 2019

doi:10.5296/ijrd.v6i1.14230

URL: http://dx.doi.org/10.5296/ijrd.v6i1.14230

\begin{abstract}
The conventional and traditional regional analysis seems to gradually changing focus, content and hermeneutic optic. The regional analysis of past seems increasingly saturated, being
\end{abstract}


incapable to interpret and propose policy solutions that originate primarily from the potential of local development, innovation and entrepreneurship. To this end, new, multidisciplinary approaches of local development seem to prevail progressively, leading the study of development to the analysis of dynamically evolving localities.

Keywords: Regional analysis, Local development, Innovation environment, Entrepreneurial dynamics

\section{Introducing and Positioning the Question: A Move from Traditional Regional Analysis toward the Dynamics of Local Development}

The first quarter of the $21^{\text {st }}$ century appears to emerge as a field of multiple restructurings and reorientations, of all the realities and the underlying explanatory theories.

The restructuring of globalization, which initiated during the end of the past decade, have caused deep alterations in the ways economics and all other social sciences understand their field of research (Bhattacharya, Khanna, Schweizer, \& Bijapurkar, 2017; Laudicina \& Peterson, 2016; Rodrik, 2011; Sapir, 2011; Vlados, Deniozos, \& Chatzinikolaou, 2018b, 2018a).

One research field where a theoretical rejuvenation is underway is the broader nexus of socioeconomic spatial sciences (Boschma and Frenken 2006; Briant, Combes, and Lafourcade 2010; Crespo, Suire, and Vicente 2014; Lazzeretti, Sedita, and Caloffi 2014; Martin 2009). Within these developments of economic geography, the traditional optic of regional analysis is shifting towards the study of local dynamics and causing too many rebalances. This new way of synthesizing the elements of space we think that drives to a whole new and "integrated paradigm" of development that we are going to unfold in this manuscript.

In essence, we think that this is an incubation of a profound theoretical change in spatial analysis, in terms of Paradigm mutation of Thomas Kuhn (Kuhn, 1963, 1977, 1996), since the period under study is progressively adopting new concepts, approaches, methods and exploratory routines, which are often derived from other areas of socioeconomic sciences and from the synthesis of analytical methodologies of competitive theories and perspectives. The aim of this article is therefore to critically review the core schools of thought and their theoretical derivations in the context of traditional regional analysis, and to examine the basic dimensions of the emerging local development perspective.

\section{Methodology}

In this work we will attempt: (a) a critical examination of the central analytical perspectives to the spatial phenomenon, (b) to describe the deriving theoretical stations in the traditional approach of regional analysis, and (c) to draw some conclusions that reflect the theoretical transition from the perspective of traditional regional analysis to the contemporary local development perspectives (see Figure 1). 


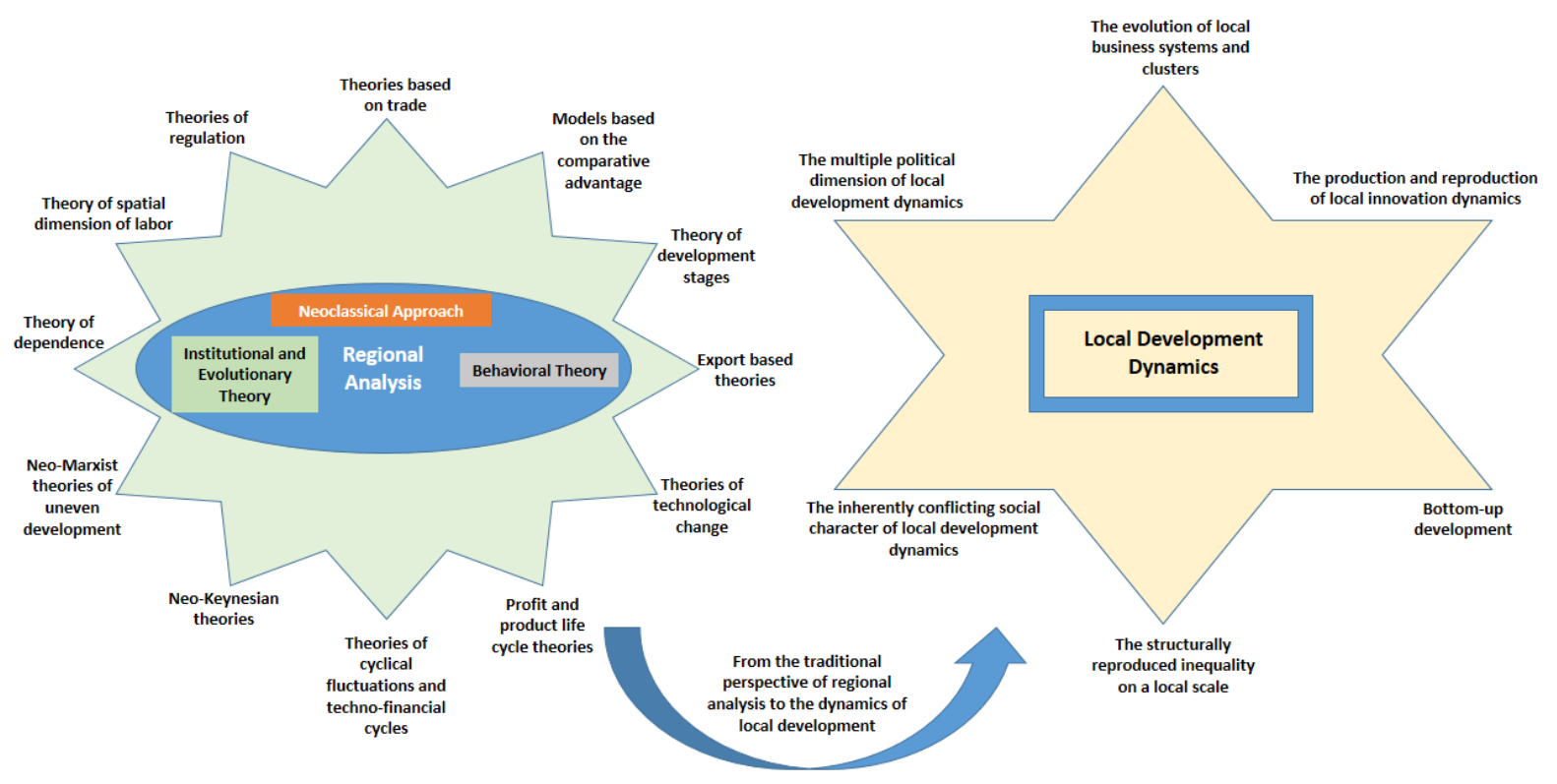

Figure 1. From the traditional perspective of regional analysis to the dynamics of local development

\section{Central Theoretical Perspectives in Analyzing the Spatial Phenomenon: A Critical Overview}

Classical economists did not specialize, at least up to the twentieth century, in the issues deriving from regional economic activities, since they believed that capital and labor could be moving freely and automatically inside the regions that can create most of their revenue. The relationship between space and location dynamics, in the first generation of related studies, appears as theoretical body of three central approaches that includes the neoclassical, the behavioral, and the institutional and evolutionary schools of thinking. The following section attempts to present in a concise and critical way these basic theoretical perspectives of understanding regional disparities, as well as their interpretations of long-term economic changes.

\subsection{The Neoclassical Approach}

This approach attempts to present a general framework for determining the most proper location for economic activity, based on narrow and unidentified historically economic components.

The "black box" business is the neoclassical theory's focus, based on supposedly full information and ability to maximize individual aspirations, coupled with decisions based solely on interpretive models of lowering operating costs. All the variants of neoclassical approach, both old and modern, have common theoretical root which combines, on the one hand, mechanistic microeconomics, where the enterprise is perceived as static and timeless transformer of output inflows and without any strategic perspective and, on the other hand, national inward-looking traditional macroeconomics, where the individual macroeconomic phenomena are rarely linked to transnational and deeper socioeconomic or institutional 
perspectives and interpretations (Belleflamme, Picard, \& Thisse, 2000; R. Boschma, 2015; Henderson \& Thisse, 2008).

Von Thünen (Clark, 1967; Thünen, 1826), Launhardt (Launhardt, 1882), Weber (Weber, 1909, 1929), Lösch (Lösch, 1954) and Palander (Palander, 1935) are the founders of the regional dimension of neoclassical approach. In particular, the works of von Thünen and later of Lösch and Dunn (Dunn, 1954) to the distribution of land uses around an urban center are the

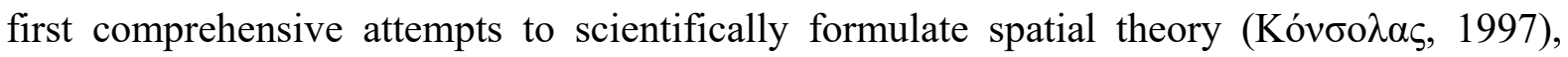
while the works of Wingo (Wingo, 1961) and Alonso (Alonso, 1964) are the basic core of the subsequent relevant analysis.

The neoclassical location-based theory focuses on the cost side, which is being determined by the territorial limits and profitability of each area. The neoclassical aspect does not, however, measure the degree of influence of local business internal factors, such as the entrepreneurial growth and strategy, which represent the most decisive factors of business relocation. In recent years, many prominent economists (Fujita \& Krugman, 1995; Fujita, Krugman, \& Venables, 1999) have reconsidered the neoclassical views of location theory within the analysis of new economic geography, based on explanatory models where location factors such as transport and labor costs and the size of the market are the major drivers of the decision to relocate.

In the background, however, the neoclassical theory, both older and recent, is following six analytically rigid assumptions as structural basis. It is a conceptual tool that integrates the model of International Trade, formulated by Heckscher and Ohlin and completed by Samuelson (the HOS model).

In particular, the conventional neoclassical theory establishes traditionally its approach on the following common working assumptions:

1. It is impossible for the productive factors to move from country to country

2. Perfect market competition is prevailing

3. International specialization of production is static, while technology is "open to all" and without restrictions

4. The firm is an automatic and ahistorical mechanism

5. There is no kind of institutional dimension in the functioning of the economy

6. There is no historical dimension in the spatial socioeconomic formations.

Based on the assumptions of the traditional neoclassical school, the basic product of neoclassical analysis, the Heckscher-Ohlin-Samuelson (HOS) model, lies in the so-called theorem of "endowment" of national productive factors that every space holds in a "static" way. This theorem also produces the rule that each spatial entity has to specialize in the production and export of those products that use a relatively abundant productive factor. Therefore, this static logic understands international specialization as condition that leads, supposedly directly, to an optimized allocation of productive factors for individual uses 
- under free trade conditions and cross-spatially. The productive factors in this model stay, of course, eternally immobilized within their national frameworks, while the trade of goods fully substitutes any need for moving capital from one country to another.

The HOS analysis, specifically, accepts largely the fundamental directions of Ricardian theory, but with a great difference: it assumes that production functions for a given product and from country to country are identical. This implies silently an automatic and unimpeded diffusion of technology at international level: something that has little to do, of course, with the present-day conditions. In practice, if the HOS model assimilates the realistic assumption of technology varying to produce a good from country to country, then any definition of national productive factors endowment loses its explanatory power. Therefore, this analysis is particularly restrictive and incapable to approach the present-day cross-spatial dynamics in the context of globalization (Note 1).

Undoubtedly, the HOS model is logically consistent internally and uses remarkably its cognitive tools. However, these conditions are insufficient now. The neoclassical working assumptions, although they keep prevailing, cannot interpret the globalized socioeconomic systems today, where at least six conditions differ significantly from the past.

1. Productive factors (capital, natural resources, technology and entrepreneurship and, to a certain extent, labor) no longer recognize national borders.

2. Complicated forms of incomplete competition -in particular the increasingly sophisticated forms of globalized oligopolistic competition-dominate the world.

3. There is an international specialization of production that is constantly and evolutionarily changing, within an increasingly dense, systemic and interdependent environment.

4. The Firm, the motor of the economy, is a complex entity, an evolutionary and adaptive subject that closely resembles a living organism.

5. Institutions are acquiring an ever-increasing critical impact on the dynamics of development/crisis of individual economies.

6. The historical specificity and trajectory of each socioeconomic structure are crucial for a successful integration in globalization.

In the background, the neoclassical theory is unavoidably sterilizing at least three main analytical dimensions of the dynamics of globalization, that is why appears now largely saturated in interpretative terms.

Firstly, key actors in globalization are insufficiently explained. The private enterprise is explained through a static production function and nothing more, the institutional interventions of the social (state or other) entities, at every level of the system operation, are marginalized, and the historical dynamics of the spatially established socioeconomic systems is simply ignored.

Secondly, neoclassical science "forgets" about the globalized interconnections between socioeconomic spaces. All economic phenomena are separated from the social ones, while the 
narrow economic aspects are perceived within a rigid ethnocentric framework, where the nation-state is not one of the analytical levels (local, national, regional, global) but the strict, exclusive basis of neoclassical analysis.

Thirdly, the increasingly disruptive sectoral innovation in globalization is not observed by the neoclassical tradition. New technology is almost always equated with new capital equipment and nothing more. There is no study about the aspects of knowledge creation, experience and learning, while new technology in the context of sectoral competition is strictly exogenous (like "falling of the sky"), innovation means almost always some "narrow-thinking" acquirement of new machinery with a statically embedded knowledge, and finally the concept of crisis remains within the context of neoclassical tradition a theoretical condition "to avoid" and not the necessary basis for the production and reproduction of new socioeconomic conditions.

In conclusion, all of these analytical constraints remove from the contemporary branches of neoclassical school any possibility of valid theoretical understanding of the dynamics of globalization. In practice, the conventional neoclassical thinking is now largely alienated from the modern globalized reality, at every level.

Therefore, the critique of neoclassical economic thought today continues to grow even in traditionally conventional theoretical fields (Gilpin \& Gilpin, 2001). Nevertheless, neoclassical theory, to this day, still maintains a dominant position in the "orthodoxy" of conventional economic science. As a result, neoclassical tradition is not only wrongfully considered "scientifically responsible" on the fields of international trade and investment, but also on the broader fields of globalization and spatial development.

\subsection{Behavioral Theory}

Behavioral theory, in its spatial perspective, not only perceives enterprises as active subjects with incomplete information and limited choices of rational optimization, but also as active coordinators of the production process that deviate from the mechanistic willingness of short-term profitability maximization.

This particular theoretical perspective was developed, among others, by Simon (Simon, 1955), to whom is usually attributed the introduction of this perspective, by Cyert and March (Cyert \& March, 1963), and by Townroe (Townroe, 1983) who underlined the importance of enterprise internal factors, such as personal choices and capacity, conditions that contradict with the factors of cost highlighted by neoclassical tradition.

For Simon (Simon, 1947, 1973, 1996), the entrepreneur is neither capable to gather the necessary information for a decision, nor his or hers analyzing time is abundant and, therefore, the idea of optimal choice together with the notions of maximization and minimization is simply an ideal construction that has no practical application.

On this direction of understanding, it is clear that a business do not have -and could never have- direct access to any "perfect information" and that there is no "perfectly" rational decision, but on the contrary every business person draws initial information from the 
problem and then acts accordingly. Nobody in practice is capable to acquire infinite information, of infinite precision, and has infinite abilities and time. Nothing in everyday reality is absolute and perfect in the organizational administration. Simon called this logical thinking of decision a "satisfying solution", which is far from claiming any "ideal" solution. He argued that any administration is de facto limited to a sufficiently good solution, without being able, by nature, to claim any "optimality". Thus, Simon replaced the rigid model of one-dimensional "economic man", that until then was unquestionably assimilated by the classical administrative perspective, with the act "within reasonable limits" notion (Nonaka \& Takeuchi, 1995).

Therefore, the basis of behavioral theory is how the business perceives, compiles and evaluates in "real conditions" the information and factors that influence the choice of location. Subsequently, the relevant models of "garbage can" and organizational "sensemaking" emerged in management theory. Specifically, Simon's pattern questioned by Cohen, March and Olsen (Cohen, March, and Olsen 1972), who proposed the "garbage can" model, by underlining the unreasonable and vague nature of human problem resolution and decision-making within the organization. They argued that any organization consists of a set of feelings and issues, related to situations where first you make a decision and then this decision comes to the surface. In this model the opportunities for choice are equal to the "garbage" and the problems, solutions and decision-makers are the "garbage can". Nothing in this process is similar to any straightforward and linear decision-making process such as classical management implies. This model perceives, on the contrary, the organization as system that gives retrospectively meaning to the events and not a system of planning and rational decision-making (Weick, 1993).

Thus, in general, behavioral theory manages to drastically enrich the theory of spatial phenomena, by analyzing centrally the decision-making process of specific-operational and structural- actors within socioeconomic "gameplay".

\subsection{The Institutional and Evolutionary Theory}

The institutional and evolutionary theory in spatial analysis "liberate" analytically the historical dynamics of the spatially established socioeconomic systems. Institutional theory begins its hypothesis by a dynamic environment where decisions are not taken by enterprises, but are due to the values and cultural background where the enterprise operates. This stream of thought during the 1980 s came into the surface, by trying to explain the spatial economic processes with the lenses of social institutions.

In the institutional approach location decision results from business investment strategies, which derive from negotiations with suppliers, the state, trade unions and other institutions, while taking into account business-related factors such as prices, wages, taxation, infrastructure, etc. As will discuss in more detail below, the related and deriving from institutional approach school of "industrial districts" focuses on relationships between businesses and local society, in the sense of formal and informal social, economic and political relations as determinants of long-term economic development (Amin, 2000; Becattini, 2002). 


\section{$\triangle$ Macrothink}

The evolutionary theoretical perspective is following a converging direction. In particular, as evolutionary model we mean the scientific methodological framework in social sciences which attempts to apply to the study of socioeconomic phenomena the principles governing the appearance and reproduction of biological types of the earth ecosystem, through the principles of genetic differentiation and natural selection.

In particular, the branch of evolutionary economics is now part of the backbone of modern economic science (Friedman, 1998a, 1998b; Witt, 2008), although retaining several elements of fertile "heterodoxy", inspired mostly by evolutionary biology. Evolutionary economics are studying specifically the complex socioeconomic interdependencies: competition, development, structural changes, within an environment of permanent scarcity and with a methodological perspective that resembles the "living" and "biological" procedure (Hodgson, 1999). In particular, evolutionary economics focuses on the study of processes that transform the economy and society, with reference not only to business, but also to industry, employment, production, commerce and distribution, social stratification and social mobility through the actions of various actors / players.

This theoretical perspective lays also the ground to perceive the dynamics of globalization as process of "biology", where there are central concepts such as "natural selection", survival, development and reproduction of both the actors and their underlying structures. Not only that, but in this context innovation can also be perceived as "organic", within a perpetual evolutionary process.

On this basis, evolutionary economics also studies necessarily the technological and institutional innovation where there is the constant creation and test of a variety of ideas or applications. If the dynamics of survival value is more powerful than the consumed effort and the competitive alternatives, then these ideas and applications are successful -otherwise they get rejected. In this way, the focal point of analysis shifts to non-equilibrium processes that transform unceasingly the economy "from within" (endogenously). These transforming processes arise in turn from the choices of various actors (players) that guide structural change.

The evolutionary perspective, in contrast with the institutional approach, is only recently active in the matters of economic geography. According to Martin (Martin, 2008) because until recently many economic geographers were tending to consider the notions of "evolutionary economy" and "institutional economy" identical, this explains the minimal interest of evolutionary approach to economic geography.

\section{Important Theoretical Milestones of Traditional Approaches to Regional Analysis}

The previous three central theoretical perspectives, with their competitive and complementary co-evolution, acted as a nursery for multiple distinct approaches to the phenomenon of regional development. These exactly are the approaches we present in the following lines of this paper. 


\subsection{Theories Based on Trade}

According to Adam Smith (Smith, 1776), the principle of absolute advantage based on specialization and different productive costs, economies of scale, and redistribution of production and trade can possibly increase the level of current incomes (Debaere, 1998; Rivera-Batiz \& Romer, 1991; Skinner, 1988). On a similar basis, Ricardo (Ricardo, 1817) put forward a differentiated approach, that is, the principle of "comparative advantage" on a national basis, supporting that if a nation does not hold absolute advantage on any productive sector, then it is better to utilize a comparative advantage by focusing the production on less perfect productive field. Subsequently, Bertil Ohlin (Ohlin, 1933) linked trade to movement of productive factors between national regions, based on two assumptions: (a) to the high degree of mobility of productive factors and (b) to the full integration of markets of national regions, despite any local variations.

Regarding the results of trade, Paul Samuelson (Samuelson, 1948, 1949) proposed that international trade tends to equalize incomes. The "neo-factor proportions" theory extends the Heckscher-Ohlin theory by adopting the real and rejecting its unrealistic assumptions. In recent years, international trade research have focused on what Krugman (Baldwin, 1988) called "silent revolution" and includes theories that accept, as opposed to the classical view and dominant theory of comparative advantage, the hypothesis of increasing returns to scale. In this respect, Krugman's theory of new economic geography (Krugman, 1991) relates, to a regional or transnational level, the increasing returns to scale with transport cost, while gives great importance to the factor of demand for defining the patterns of trade.

\subsection{Models Based on Comparative Advantage}

In models based on the principle of comparative advantage, the import of a good in a country or region depends, ceteris paribus, on the level of demand for that good, while the share of transport cost, although it may reduce the volume of trade, it will not stop the exporting of that good. On the contrary, Chipman (Chipman \& Winker, 1992), Davis (Davis \& Weinstein, 1996) and Deardorff (Deardorff, 1995, 2004, 2005) applied and tested empirically the theory of increasing scale returns, arguing that these economies direct producers to concentrate the production process to one or more products in an area. If a national region has high-level demand for the same products, then it transforms into an ideal location for the production process and initiates an export activity (Krugman, 1980).

However, if transport costs burdening trade are present, then a high-level demand for a good causes opposite predictions. For comparative advantage theory the economy will be importing the good, while for new economic geography the economy will start exporting activity (Davis \& Weinstein, 1996).

\subsection{Theory of Development Stages}

Rostow proposed perhaps the most well-known relevant development theory as conceptual basis also for regional development, based on five stages that form the paths of a nation (or even a region) toward economic development. The idea of economic development through a series of stages by Rostow adopted the views of various German economists of the late $19^{\text {th }}$ 
century (e.g. the works of Friedrich List).

Although Rostow formulated a more systematic theory, he did not directly include the spatial aspect of development (Azariadis, Bullard, \& Ohanian, 2004; Guillén, 2001; Rostow, 1952, $1956,1959,1960,1963)$.

\subsection{Export Based Theories}

Export based theories distinguish economic activities to basic or export-oriented and non-basic or activities related to services for internal consumption.

Export based theories focus, on one hand, on the demand-side without downgrading how important is the supply-side, but, on the other hand, they did not particularly address the implications of government spending, local entrepreneurship and the impact of technology and innovation on regional development (Armstrong \& Taylor, 1993; Chinitz, 1966; Healey \& Ilbery, 1990; Muller, 2001).

\subsection{Theories of Technological Change}

The review of past and current literature on economic development shows that technological changes are the main driving force of modern economies. This theoretical research of technological changes broadens the field of economic development since it investigates not only how economies interact with a given set of technological changes, but also how these different mechanisms interact socio-economically (Maurseth, 2003).

Kuznets (Kuznets, 1973) supported the idea that a technological revolution marks the era of a new economic beginning. He also argued that improving productivity is not only based on capital sufficiency, but also on capital quality, on the process of organizing production and the quality of labor force.

Posner (Posner, 1961) used the term "technological gap" to describe the idea that international trade is the condition to make monopolistic profits based on technological superiority. On the same issue, more recent studies at national level have shown that national development results from rapid adoption and diffusion of new technologies, while nations that drive technological innovation on radical industrial technological applications and new sectors are leading the global economy (Hall, 2004; Reuveny \& Thompson, 2001).

The advantage of technological innovation, translated at terms of monopolistic power, is present as much as Posner's "imitation lag" parameter imposes on other countries to imitate and adopt the leading country's technology. According to Posner, the time-frame of "imitation lag" can be distinguished in two phases. The first corresponds to the zero-exports time-frame because of the "demand lag". Countries not familiar with the new product are unable to adapt their consumer habits and, as a result, the country of origin cannot easily export the innovative product. The second phase refers to the "reaction lag", which is the time lag of other regions consumers to express demand for the particular product.

Metcalfe and Soete (Metcalfe \& Soete, 1984) underline that trade can happen because of the difference between national rates of demand volume diffusion increase and time lags of 
technology transfer. Krugman (Krugman, 1985) standardized the earlier view of factors affecting the long-term comparative advantage to a model of neoclassical direction where technology between two countries varies not only in degree but also in produced goods and level of technology. Krugman model predicts that technological progress in the leading country, which widens the technology gap with the lagging-behind countries, creates trading opportunities and as a result there is a widening gap between the real incomes of the countries in-trade. On the opposite side, however, the convergence process of the lagging-behind countries progressively deprives the advantages of trade (Laursen \& Meliciani, 2000; Lee \& Vivarelli, 2006; Vivarelli, 2004).

\subsection{Profit and Product Life Cycle Theories}

At the level of conceptual approach, innovations and their creators share three common features: novelty, improvement and uncertainty. These hypothetical features direct the issue of innovation in two interpretations. The first relates innovation to the life cycle of a product (Gordon \& McCann, 2000), while the second promotes innovative products in relation to the environment. Markusen's (Markusen, 1985) theory of profit cycles links technologically advanced regions and countries, with innovation, trade and profit cycle of corporations. The "product life cycle" theory includes the characteristics of novelty, improvement and uncertainty according to a typical form of five phases.

First is the "negative profits" phase and corresponds to the first phase of a business. Second is the "superprofit" phase when the business creates the innovative product and a temporary monopoly in the market since there is no competition. Third is the "normal profits" phase when the market matures, there is a consequent lack of dynamism and new entrants are entering into the market and distracting parts of sales. Fourth is the post-maturity phase and features a level of business profits ranging from normal "plus" to normal "minus". At this stage, profits from the product either increase due to successful profit-making oligopoly, or decrease as a result of successful competition of other businesses. Fifth, finally, is the "negative profits" phase that reflects the sector's stage of uselessness.

Simon Kuznets (Kuznets, 1980) was the economist that largely established this "life cycle" theory in the industrial sector and his basic finding was that, after the first production and innovation, a product is going to follow a bell-shaped path. First will grow to a great extent and then will follow a bending path until the stage of maturity, just before new products appear in the market.

\subsection{Theories of Cyclical Fluctuations and Techno-Financial Cycles}

Following a Marxist-type analysis, Kondratiev (Kondratieff \& Stolper, 1935) argued that capitalist-type economic growth is experiencing a period of fluctuation around phases of economic growth and economic downturn. The theory of "long circular fluctuations" or Kondratiev waves was based on the study of per-capita indices behavior and values during the $12^{\text {th }}$ century, expanding the findings of this study into the economic, social and cultural life of societies.

Very close to the theory of cyclical fluctuations is the theory of "logistic cycles" by Cameron 
(Cameron, 1970), who believed that, contrary to the theory of cyclical repetition of economic expansions and contractions of the earlier theory, logistic cycles synthesize an analogous movement to the statistical logistic curve, which consists of a prosperity-expansion phase of the economy, followed by a corresponding recession-contraction.

The regions that are leading in terms of exports during the prosperity phase are poles that attract workforce and new businesses, thus increasing their leading financial position. On the opposite side, during the recession period, companies are trying to exploit the capital of existing innovation to new exports due to high competition and reduced demand. This phenomenon can lead to new re-locations and re-balances of the regional development map, while companies that do not produce modern goods may disappear (Harle, Moisio, \& Aalto, 2016; Knox, Agnew, \& McCarthy, 2008).

\subsection{Neo-Keynesian Theories}

Contrary to the classical theory predictions, Keynes in his "General Theory" in 1936 underlined that a wage cut does not cure unemployment because of the drop in active demand (Chisholm, 1990). So, contrary to the classical perspective that underlined the role of supply, the role of demand through export development and state intervention is of Keynesian influences (Filho \& Scorzafave, 2001; Thirlwall, 2006; Vines, 1987).

According to Keynesian theory, differences in growth rates of production can lead to regional productivity growth inequalities, resulting in some regions making greater use of economies of scale. A fast increase of regional production growth rates increases respectively competitiveness and leads to a process of higher production growth rates and greater competitiveness. In a similar process, development, besides its self-reinforcing dimension, creates powerful endogenous forces that create inter-regional inequalities, and yet, as the cumulative process strengthens wealthy regions, powerful centripetal forces further weaken the under-achieving ones.

The fast-growing regions attract capital and labor due to higher returns and wages, and from this point onwards the process follows a self-supporting path of development where, in a later stage, the sufficiency of capital and labor will lead through the Verdoorn law (Verdoorn, 1980) (Note 2) and economies of scale, to more specialized regional product. On empirical level, according to Verdoorn law, the per-capita income development, closely related to labor productivity, is positively correlated to the product produced. Fingleton and Lopez-Bazo (Fingleton, 2001; Fingleton \& López-Bazo, 2006) argue that the Verdoorn model offers a more realistic description of the regional development process and it is more compatible to specific endogenous models (Pfaffermayr, 2007). In neo-Keynesian line of thought, Kaldor (Kaldor, 1970; Kaldor, Targetti, \& Thirlwall, 1989) also argues that the per-capita regional product depends to the economies of scale growth and gradual specialization, while coupled with the Verdoorn principle a strong statistical correlation between the product produced and (endogenous) productivity growth is taking place.

\subsection{Neo-Marxist Theories of Uneven Development}

The neo-Marxist structural theory of spatial inequalities deals with the respective inequalities 
by focusing on industrial structures and inequalities between demand and supply. The neo-Marxist theory of uneven regional development is based on deliberate activities of the capitalist class at the expense of workers class. Both Marxist and Neo-Marxist theory argue that the market does not play an important role in interpreting factors of development, as opposed to the labor theory of value, which explains both equilibrium values of products and spatial concentration of a large number of industries (Chisholm, 1990; Kotz, 2003; Mcdonough, 1995).

Another view of neo-Marxist theory is that spatial concentration of production does not result from systematic market orientation or scarcity of natural resources between different regions, but it is a phenomenon induced by the highly-mobile capital, which offers many exploitation opportunities and in particular in the construction industry.

Subsequently, another view is the "lower circuit" that refers to local needs of urban population and includes types of labor-intensive industrial activity and small-scale commercial activity. According to Santos (Santos, 1977), some industrial activities of the "upper circuit" are internal, in the sense that industry is disproportionately concentrated in central metropolises. At the same time, despite the highly-mobile capital, between the "upper" and "lower" circuits there are significant inequalities because the "lower circuit" activities are unable to attract capital.

To a large extent, the "family" of neo-Marxist analyses of international capitalism has been the victim of its easy success in the "revolutionary" decades of the 1960s and 1970s.

\subsection{Theory of Dependence}

The basic view of dependence theory, which represents almost all the individual theories, is that between the center and periphery there is technology, in the sense of a region's inability to form autonomous and dynamic processes of technological innovation as opposed to central countries that control not only technology but also the production systems (McDonough, 2007).

Frank (Frank 1976; Frank 1967) rejects the idea that underdevelopment is a situation equal to tradition or setback and by adopting the "development of underdevelopment" notion supports "statically" a widening economic gap of dependence between developed and underdeveloped nations. The idea is that global distribution between metropolises and their satellites, despite the change in forms of monopolistic metropolises power, sustains a system of surplus expropriation from satellites to metropolises and specific regions are developing to the detriment of others.

According to the rationale of dependency theory, dependence itself distorts the productive structures of less developed countries. This imposes a destructive extroversion to their economies by requiring them to specialize and export to the Center a limited number of relatively low-technology products. Because of their structural dependence, within the underdeveloped economies inevitably sectors of completely different qualitative content and behavior (dualism) co-exist: 
- On the one hand, the modern, developed sector that mainly produces for the international market.

- On the other hand, the "predominantly internal", endoscopic, traditional and underdeveloped sector.

These two sectors remain "unconnected" and in this way the results of any development of modern sector do not diffuse to the rest of the economy.

One conceptual distinction and co-existence between traditional and developed capitalist forms within a socioeconomic formation (dualism) is undoubtedly useful. However, the assumptions of "discontinuity" and "autonomy" seem largely misplaced. There are today multiple cases where it is clear that these two supposed "completely separate" productive worlds within a less developed national economy are not as independent and unrelated as this version of Dependency theory assumes.

Instead, almost everywhere nowadays, less developed capitalist enterprises are progressively connecting and co-evolve with more developed capitalist enterprises. Multiple and increasingly complex sub-contracting relationships, technology transfer, managerial know-how transfer, acquisitions, shareholding activities and broader strategic alliances are constantly converging those two separate entities.

\subsection{Theory of Spatial Dimension of Labor}

During the 1980s, the three main analytical categories of regional development, the neoclassical, Keynesian and monetarist theories, faced criticism because of their inability to cope with the recession, the inflationary pressures, the rise of unemployment and international competition. As a result, the theory of labor, which only the neoclassical analysis had investigated, emerged in economic literature.

While the structuralist theories observe the capitalist class dominating the working class, labor theory determines the rate of natural growth of population and responds to wage-level changes. Central or hegemonic regions with skilled labor attract central administrative services as well as research and development activities, leaving behind the productive process in the remote low-skilled labor regions (Healey \& Ilbery, 1990; Sayer, 1992; Storper, 1991). Increasing competition in export markets leads to the search for effective ways to cut production costs, with companies taking advantage of the secondary sector of the dual labor market and relocating their production to regional low-cost labor areas.

\subsection{Theories of Regulation}

One of the most fertile, newer theoretical platforms in theoretical research on socioeconomic development is the so-called "School of Regulation", emerged during the 1970s in France. One fundamental of theoretical type of approach is that each socioeconomic system has and mobilizes historically sequential development models.

Specifically, a development model of each economic system is an evolutionary synthesis between an accumulation status and a form of regulation of economic behavior within each 
historically identified society. According to M. Aglietta (Aglietta, 2010), one of the founders of this stream of socioeconomic research, the reason for establishing a "theory of regulation" of capitalism lies in the growing sense of dissatisfaction of more and more theorists against the conventional / established body of knowledge called economic science.

This dissatisfaction, in particular, is due first to the inability to analyze economic movement that specific subjects are experiencing in time: in other words, the inability to take into account the real history of economic phenomena. And, second, the inability to express the social content of economic relations and to interpret economic power and conflicts. On the contrary, the School of Regulation suggests a re-focused economic logic based on the birth and death of institutional forms, within an integrated context of the socioeconomic subject.

According to regulation theory, capitalistic economies develop accumulation stages and build a particular form of balance of production processes and work organizations. Special attention should, however, be paid on transition periods of intense crises and profound upheavals. This transition/crisis period re-organizes the regional industrial base and accelerates the decline of the earlier accumulation phase of industrially developed regions, leading to new industrially developed or rejuvenated regions that are inevitably linked to the next stage of accumulation (Aglietta, 2000; Benko \& Lipietz, 2000; Boyer, 2004; Lipietz, 1986).

Aglietta (Aglietta, 1997) proposed four stages of capitalistic accumulation. First is the "industry" stage that corresponds to the grouped workers of a productive system. Second is the "industrialized production" stage where the need for increased production introduces mechanization. Third is the "scientific administration" and "Fordism" stage where the scientific administration includes techniques necessary for more efficient distribution of time and ergonomics, while the fordistic system includes assembly techniques in the production process. Finally, the fourth "neo-fordisticc" stage extends the earlier stage by applying computer micro-technology and results in further widening of productivity and fragmentation of labor force.

Perrons (Perrons, 1981), in the same direction, argued that the techniques presented in industrial production process from the mid $-16^{\text {th }}$ to the early $18^{\text {th }}$ century led to industrial concentration of production in urban locations. In parallel, during the early 1990s the concept of sustainability also emerges in development theory, mostly by the Brundtland Report (World Commission on Environment and Development, 1987) that defined sustainable development as "development that meets the present needs without weakening the future generations ability to satisfy their own needs".

\section{Critical Conclusion: From the Traditional Perspective of Regional Analysis to Modern Approaches of Local Dynamics And Evolution}

The previous short description of the historical evolution in theory of spatial development proves a gradual conceptual enlargement and methodological enrichment that tries progressively to include not only the (narrowly perceived) economic dimension but also the social, political, cultural and ecological dimensions. Older approaches seem to have entered a 
rapid process of analytic modernization and increased interaction. And not only that, but it seems that a multitude of new theoretical spaces and interests are able to offer to this methodological transition and restructuring a new variety of categories and tools (Table 1).

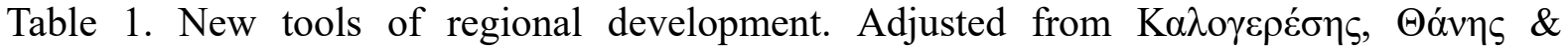

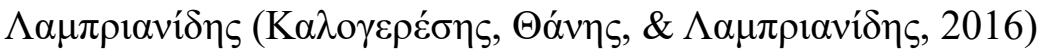

\begin{tabular}{|c|c|c|}
\hline $\begin{array}{l}\text { Conceptual tool / } \\
\text { field }\end{array}$ & Short description & Related literature \\
\hline $\begin{array}{l}\text { Institution } \\
\text { institutional } \\
\text { economics }\end{array}$ & $\begin{array}{l}\text { These are anthropogenic constraints that } \\
\text { structure political, economic and social } \\
\text { interactions. They consist of informal } \\
\text { constraints and formal rules (constitutions, } \\
\text { laws, etc.), while the economy is } \\
\text { essentially understood as a completely } \\
\text { institutionalized process. }\end{array}$ & 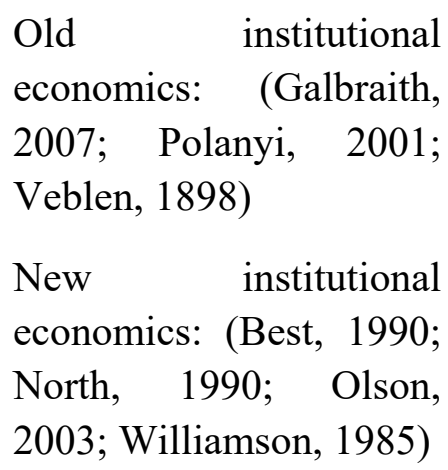 \\
\hline $\begin{array}{l}\text { Industrial } \\
\text { organization and } \\
\text { transaction costs }\end{array}$ & $\begin{array}{l}\text { These are the Californian school's } \\
\text { interpretative tools that analyze the } \\
\text { reduction in transaction costs resulting } \\
\text { from the dense interconnections between } \\
\text { businesses in high concentration areas }\end{array}$ & $\begin{array}{l}\text { Vertical networking: } \\
\text { (Marshall, 1920) } \\
\text { Horizontal networking: } \\
\text { (Jacobs, 1961) } \\
\text { School of California: } \\
\text { (Scott, 1988; Storper \& } \\
\text { Christopherson, 1987) }\end{array}$ \\
\hline $\begin{array}{l}\text { Innovation and } \\
\text { technological } \\
\text { progress }\end{array}$ & $\begin{array}{l}\text { It refers to changing production patterns, } \\
\text { ways of producing technology and } \\
\text { innovation and their impact on regions and } \\
\text { SMEs }\end{array}$ & $\begin{array}{l}\text { Theoretical core: (Philip } \\
\text { Cooke \& Wills, 1999; } \\
\text { Hadjimichalis, 2011; } \\
\text { Kaufmann \& Tödtling, } \\
\text { 2001; Malecki, 1983; } \\
\text { Schumpeter, 1934, 1939) } \\
\text { Externalities approach: } \\
\text { (Florida, 1996a, 1996b; } \\
\text { Saxenian, 1990, 1994) } \\
\text { RIS approach: } \\
\text { Asheim \& Clark, 2001; } \\
\text { Philip Cooke, Gomez } \\
\text { Uranga, \& Etxebarria, }\end{array}$ \\
\hline
\end{tabular}




\begin{tabular}{|c|c|c|}
\hline & & 1997) \\
\hline Social capital & $\begin{array}{l}\text { It refers to the collective value of "social } \\
\text { networks" (acquaintances of individuals) } \\
\text { and the trends emerging from these } \\
\text { networks for reciprocity among the } \\
\text { members. }\end{array}$ & $\begin{array}{l}\text { Theoretical core: } \\
\text { (Coleman, 1988; Portes, } \\
\text { 1998; Putnam, 1993) } \\
\text { Institutional approaches: } \\
\text { (Phil Cooke, 2007) } \\
\text { External economies: } \\
\text { (Faggian \& McCann, } \\
\text { 2009; Gordon \& } \\
\text { McCann, 2000) } \\
\text { Technological } \\
\text { approaches: (Cohen \& } \\
\text { Levinthal, 1989; Dakhli } \\
\text { \& De Clercq, 2004) } \\
\text { Learning regions: (B. T. } \\
\text { Asheim, 1996; Maskell \& } \\
\text { Malmberg, 1999; } \\
\text { Morgan, 1997) }\end{array}$ \\
\hline Embeddedness & $\begin{array}{l}\text { A business is more likely to succeed if it is } \\
\text { embedded, i.e. if it creates strong ties of } \\
\text { cooperation, reciprocity and trust with the } \\
\text { local production system. }\end{array}$ & $\begin{array}{l}\text { Theoretical core: } \\
\text { (Polanyi, 2001) }\end{array}$ \\
\hline $\begin{array}{l}\text { Technological } \\
\text { lock-in }\end{array}$ & $\begin{array}{l}\text { It refers to the evolutionary approach of } \\
\text { economic geography, according to which } \\
\text { the regions are "trapped" in "development } \\
\text { paths" which are affected by the previous } \\
\text { development of each region. }\end{array}$ & $\begin{array}{l}\text { Theoretical core: } \\
\text { (Boschma \& Frenken, } \\
\text { 2006; David, 1985; } \\
\text { Martin, 2009) }\end{array}$ \\
\hline
\end{tabular}

As a result of this reconstruction process, the following central theories are gradually emerging and strengthened, which characterize in our view the current qualitative transition of spatial analysis, from the perspective of regional analysis to the modern approaches of local dynamics and evolution.

\subsection{The Evolution of Local Business Systems and Clusters}

A modern theoretical re-orientation that is taking place currently is re-deploying the concept of developmental locally, by drawing its roots from the Marshallian inheritance of "industrial districts" (Marshall, 1879, 1919, 1920). This was also the basis of the Italian and French schools of local development (Antonelli, 2006; Aydalot, 1986; Becattini, 1975; R. Boschma, 
2005; Brusco, 1982; Camagni, 1995; Courlet, 2008; McCann \& Ortega-Argilés, 2013).

Moreover, an important contribution of this drastic re-orientation of spatial development is the Porterian "competitiveness diamond" (Porter, 1990, 2000). Consequently, today, these foundations are laying the ground for the study of business ecosystems and clusters (Hannon, 1997; Iansiti \& Levien, 2004; Lewin, 2000; Moore, 1993; Rinkinen \& Harmaakorpi, 2018; Rothschild, 1990).

These new directions seem to have radically transformed the contemporary context of local development, entrepreneurship, competitiveness and modern politics (Acemoglu \& Robinson, 2012; Aghion, Boulanger, \& Cohen, 2011; Aiginger, 2015; Dosi, 2016; Peneder, 2016; Vlados, Deniozos, Chatzinikolaou, \& Demertzis, 2018a, 2018b), by placing centrally on their systems the "living" enterprise, as a "cellular" element of synthesis of international economic flows (Vlados, 2004, 2005, 2012) (see Figure 2).

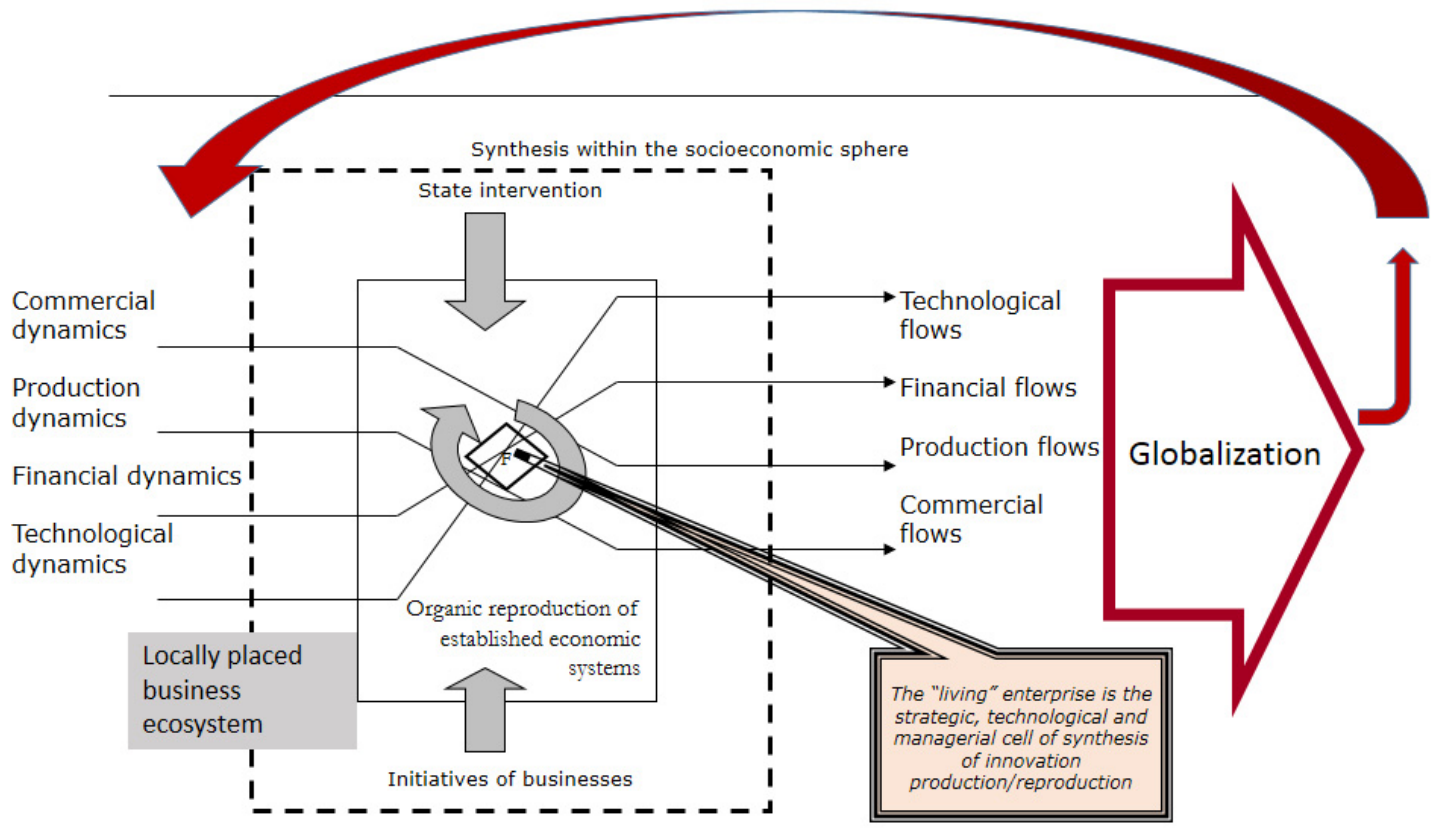

Figure 2. Local dynamics and globalization

\subsection{The Production and Reproduction of Local Innovation Dynamics}

The contemporary theory of local development gives great importance now to the notion of "innovation environment". An "innovation environment" can be a spatial set that is open to the outside and incorporates know-how, rules and "relational capital". At the same time, this environment hosts communities of actors and their available resources, human, informational and material. Of course, this is not a "closed universe", but rather a system in continuous interaction with its external, super-local environment.

The concept of "innovation environment" attempts to offer a synthesis and evolutionary socioeconomic explanation of spatial development dynamics. In particular, by using this concept, spatial development incorporates both innovative processes and socioeconomic 


\section{Macrothink}

International Journal of Regional Development

ISSN 2373-9851

2019, Vol. 6, No. 1

synergies that unfold within specific spatial contexts of local scope (Aydalot, 1984, 1986).

Overall, the key components of a local innovation system can be classified in three main categories:

1. In the know-how, which relates to the management skills of the production process

The system's know-how does not only cover technical aspects but also commercial, organizational and, in general, relational aspects of the implemented production process. In addition, know-how offers practically the ability to adapt to every kind of change arising from the integration into global dynamics.

2. In the rules that define the behavior of decision-makers and the relationships that they form with each other.

The rules of the system form the basis for particular values of "locality" while setting the prevailing principles of trust, reciprocity, solidarity, co-operation and competition.

3. In the relational capital, that is, the knowledge each member of the "environment" has for the other members.

This relational capital includes active institutions and contracts of any kind, of market or extra-market content, which are the root of network development and reproduction.

However, who innovates and how can socioeconomic systemic competitiveness and development within globalization be strengthened, according to this theoretical perspective?

Ph. Aydalot (GREMI) (Aydalot, 1986), who is the founder of this trend of developmental thinking, argues that it is not the enterprise that innovates, but the "innovation environments". In practice, creativity is always rooted in local experience and tradition and, in particular, the accumulated knowledge of "local environments" is always the basis for progress. In this way, creativity requires meeting, unregulated contact, spontaneous action, and movements that large enterprises, where everything is strictly planned, cannot offer, but are possible in "openly local terms".

Based on the above, we see that an innovation environment approach favors the process of systematically enhancing innovation capacities on a local scale, as the most proper way to enhance the overall adaptability and reproduction of competitiveness of the socioeconomic formations and, as a result, to develop within globalization (see Figure 3). 


\section{Macrothink}

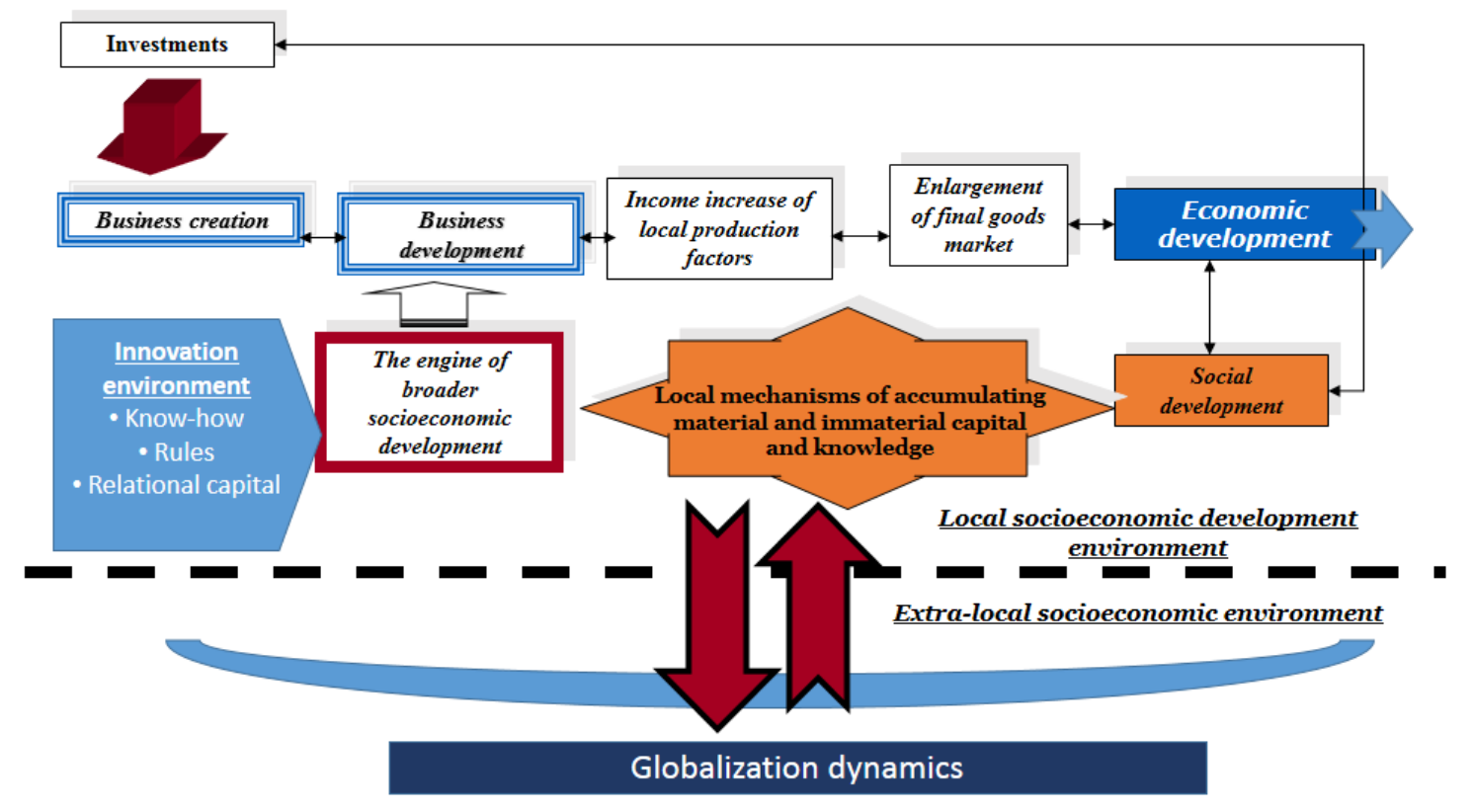

Figure 3. Innovation environment and local development

In this perspective, many contemporary research projects seem to directly and indirectly enrich the theoretical view of local development and innovation (Audretsch \& Lehmann, 2005; Balland, Boschma, \& Frenken, 2015; Carlino \& Kerr, 2014).

\subsection{Bottom-up Development}

Also, during the last decades of research, is getting clear the gradual shift of development understanding toward the "bottom". The progressive understanding of globalization dynamics that reproducing overall socioeconomic evolutionary processes and integrating all levels of space on a planetary scale are causing this theoretical shift (Benko \& Lipietz, 2000). The latter explains why local development over the last decades is "privileged theoretically", but this does not mean that development has ceased to evolve on larger scales (national and supranational), both in western economies and least developed nations. However, the observed differentiated growth in various spatial scales that highlighted the privileged local field of reference has happened within the western economies (see Figure 4). 


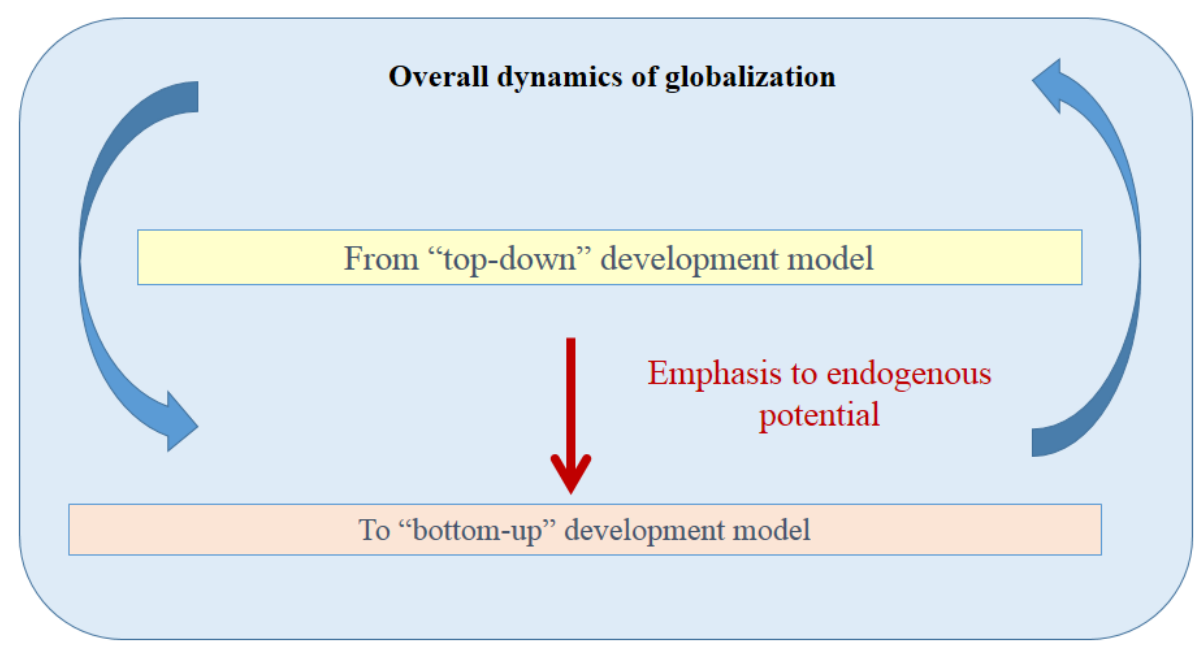

Figure 4. Modern approaches to regional development theory

From this perspective, the dimensions of locality, endogeneity, development capacity, and diffusion of growth dynamics acquire completely new content and interest (see Figure 5).

\section{Bottom-up development model}

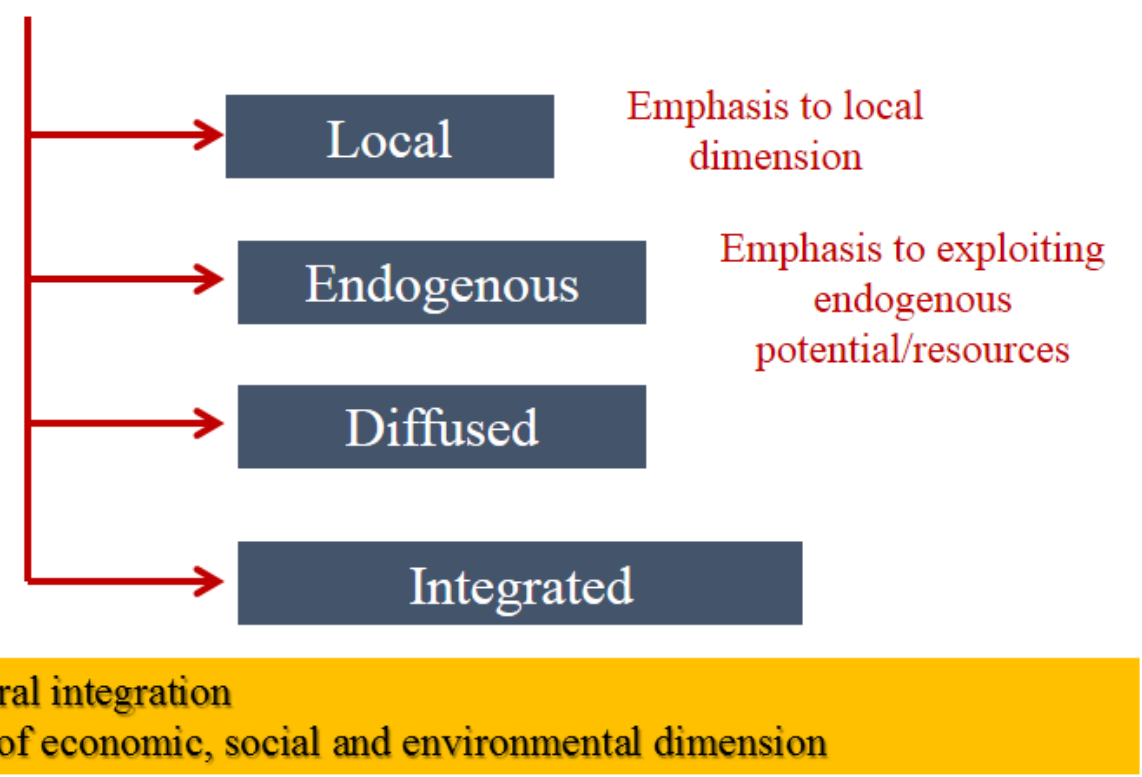

Figure 5. Modern trends of approaching the development problem

Furthermore, it seems that to meet local development needs is critical to effectively strengthen and exploit the local potential of each area, in the current context of globalization dynamics (see Figure 6). 


\section{Macrothink}

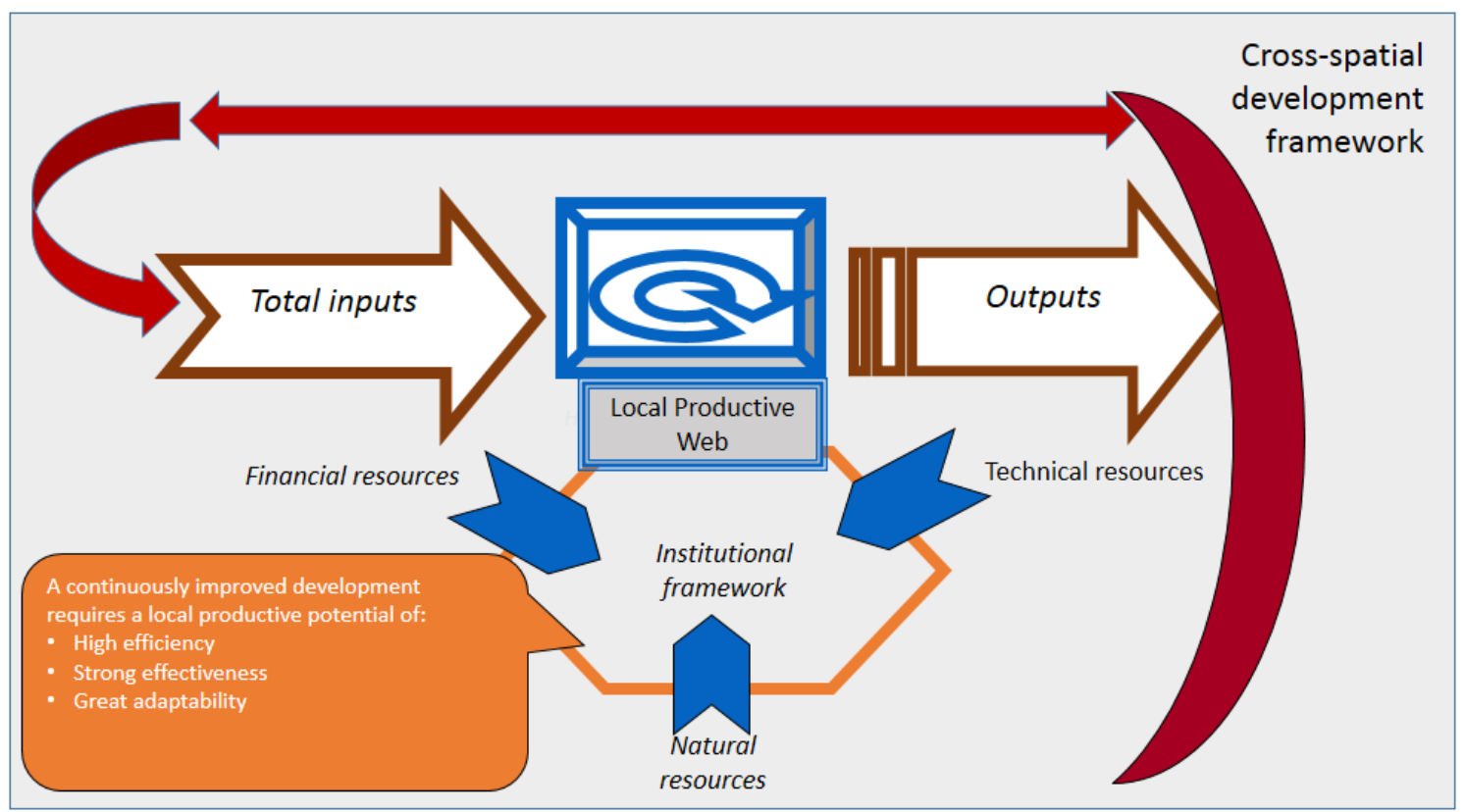

Figure 6. A modern developmental approach focuses on the effective management of local resources

\subsection{The Structurally Reproduced Inequality on a Local Scale}

On a deeper level, it is becoming progressively clear that local development itself concerns and ends in a different and unequal way for the various subjects of development; be it social categories of people or spatial-social entities (from the neighborhood and city to the national and international scale) (Pike, Rodríguez-Pose, \& Tomaney, 2007).

This structurally reproduced uneven development has attracted the interest of economists, sociologists, geographers and regional scientists already from the 1960s and beyond, despite being the privileged field of neo-Marxist critique (Harvey, 2006; Holland, 1976). Since then, scholars have argued that uneven development is inherent in the economic market system and not the result of malfunctioning. Specific areas concentrate economic activities, precisely because of competition (exploitation of economies of scale and concentration), and create "winning" or "losing" regions. Inequality between locations and regions has inherently the evolutionary tendency to widen, but often successful government interventions -although in special cases market forces are effective as well- can temporarily reverse this trend and reduce inequalities. These observations have also prompted Keynesians of different scopes and ideologies to carry out policies to reduce regional disparities by promoting spatial redistribution options.

Nowadays, a re-positioned theoretically inequality seems to progressively include, in a more complete way, all local dimensions of production and reproduction of development (Araujo, Ferreira, Lanjouw, \& Özler, 2008; Tomaskovic-Devey \& Roscigno, 1997).

\subsection{The Inherently Conflicting Social Character of Local Development Dynamics}

In addition, it has gradually become clear in the context of regional development that a 
spatially targeted development intervention has different effects on different social subjects; an intervention that can favor different social groups and at the same time marginalize others. This also highlights how significant is ideology and politics both for the "reading" of developmental issues and for legalizing interventions (Hadjimichalis \& Hudson, 2006, 2014). And in this sense, planned or non-developmental processes are a field of formation and dialectic reproduction of social contrasts between the actors of socially interdependent geographic scales. These geographical relationships range from indifference and consensus to rivalry and conflict with intense spatial references.

And at this level of analysis it seems that the framework of local dynamics offers now a new, highly fertile point of view (Cox, 1998; Cumming, Cumming, \& Redman, 2006).

\subsection{The Multiple Political Dimension of Local Development Dynamics}

Lastly, important feature is also diversity and heterogeneity, which characterize the repertoire of local and regional development policies. There is always a different meaning and political context within every integrated policy (Newman, Johnston, \& Lown, 2015).

As shown in Table 2 by Pike et al. (Pike, Rodríguez-Pose, \& Tomaney, 2006) (horizontally read), for each different dimension of local/regional development policies there are distinctions depicted in the second and third column, expressing the extremes of each dimension. However, the distinctions are extreme and bipolar and of course there are many intermediate expressions and combinations. For example, the "local-regional" development policy could combine "top-down" and "bottom-up" policies, or a policy "focus" could combine exogenous and indigenous development, and so forth.

Table 2. Distinctions in local and regional development policies. Adjusted from Pike et al. (Pike et al., 2006)

\begin{tabular}{|c|c|c|}
\hline \multicolumn{2}{|l|}{ Dimension } & Distinction \\
\hline Approach & Absolute & Relative \\
\hline Autonomy & Local, regional & National, supranational \\
\hline Direction & Top-down & Bottom-up \\
\hline Emphasis & Strong & Weak \\
\hline Focus & Exogenous & Indigenous \\
\hline Institutional lead & State & Market \\
\hline Inter-territorial relations & Competitive & Cooperative \\
\hline
\end{tabular}




\begin{tabular}{|l|l|l|}
\hline Measures & 'Hard' & 'Soft' \\
\hline Objects & People & Places \\
\hline Rate & Fast & Slow \\
\hline Scale & Large & Small \\
\hline Spatial focus & Local & Regional \\
\hline Sustainability & Strong & Weak \\
\hline
\end{tabular}

This shifting of the dominant "repertoire" seems associated not only with social and ideological issues addressed before on this paper, but also with the issue of regional development itself (Table 2, for example, distinguishes the absolute from relative regional development).

Accordingly, it seems that today a profound change of vision is gradually getting established. The dominant philosophy of intervention to strengthen local socioeconomic systems, on an international scale, moves away from the traditional regional policy paradigm, towards a more sophisticated and complete (see Table 3 ).

Table 3. Regional policy has been changing. Reproduced from OECD (OECD, 2009)

\begin{tabular}{|l|l|l|}
\hline & Old paradigm & New paradigm \\
\hline Objectives & $\begin{array}{l}\text { Compensating temporarily for } \\
\text { location disadvantages of } \\
\text { lagging regions }\end{array}$ & $\begin{array}{l}\text { Tapping under-utilised potential in all } \\
\text { regions for enhancing regional } \\
\text { competitiveness }\end{array}$ \\
\hline $\begin{array}{l}\text { Unit of } \\
\text { intervention }\end{array}$ & Administrative units & Functional economic areas \\
\hline Strategies & Sectoral approach & Integrated development projects \\
\hline Tools & Subsidies and state aids & $\begin{array}{l}\text { Mix of soft and hard capital (capital stock, } \\
\text { labour market, business environment, } \\
\text { social capital and networks) }\end{array}$ \\
\hline Actors & Central government & $\begin{array}{l}\text { Different levels of government; private } \\
\text { sector actors, civil society }\end{array}$ \\
\hline
\end{tabular}

A clear conceptual and methodological shift is unfolding; the central priority now is to build 
local mechanisms to further develop knowledge and innovation (see Figure 7).

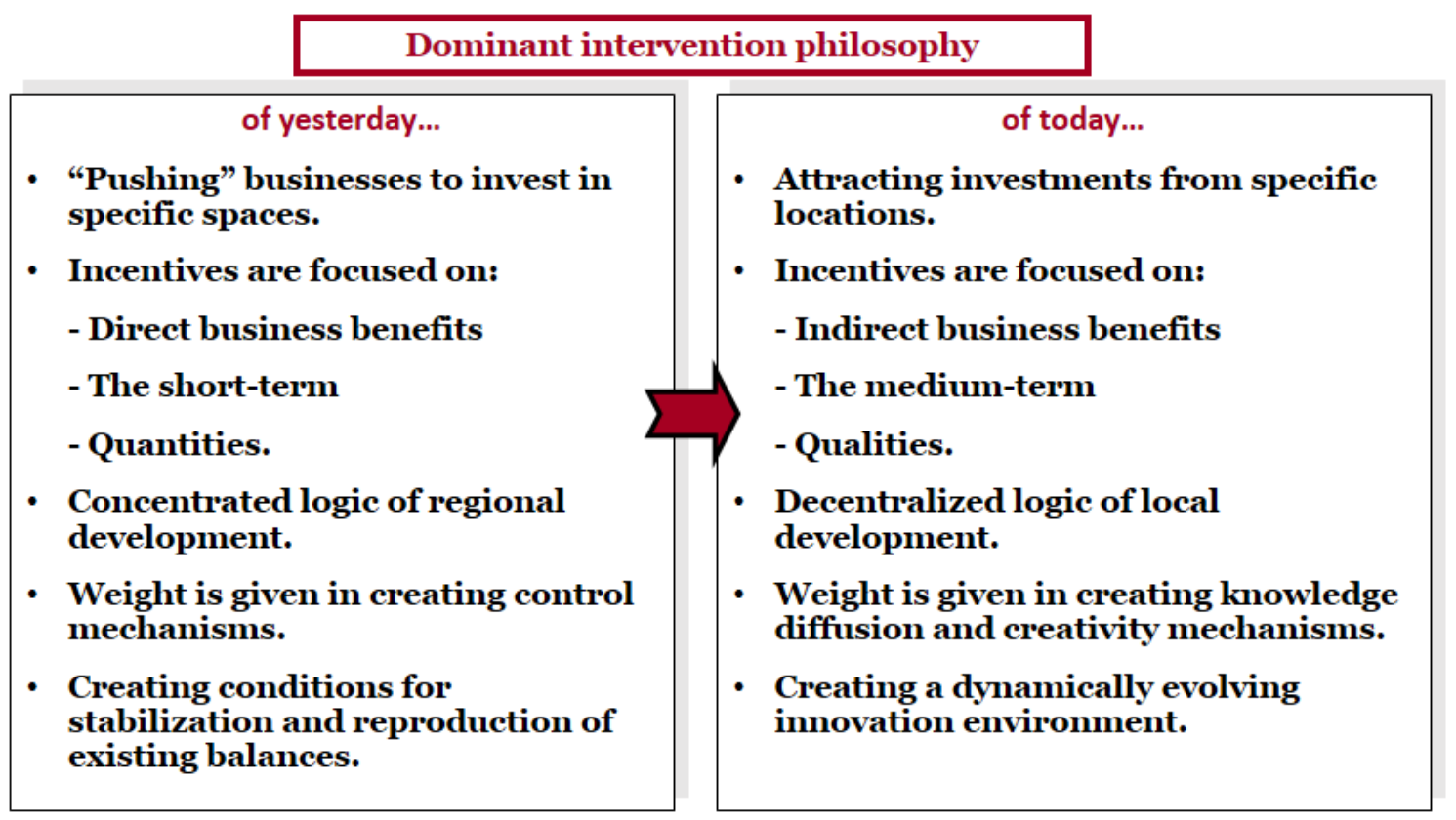

Figure 7. The emerging reasoning of strengthening all local socioeconomic systems

Finally, what we consider worth exploring in the future is to explain even deeper the formation and evolution of various local development theories: to examine, at the same time, the evolutionary course of development, the changing repertoire of development interventions and the political/ideological aspects that are directly related to theoretical tools that support specific practices and interventions.

\section{References}

Acemoglu, D., \& Robinson, J. A. (2012). Why nations fail: the origins of power, prosperity, and poverty (1st ed.). New York, NY: Crown Publ.

Aghion, P., Boulanger, J., \& Cohen, E. (2011). Rethinking industrial policy (Policy Briefs). Bruegel. Retrieved from https://econpapers.repec.org/paper/brepolbrf/566.htm

Aglietta, M. (1997). Régulation et crises du capitalisme (Nouv. éd. rev. et corr., augm. d'une postface inéd). Paris: Jacob.

Aglietta, M. (2000). A theory of capitalist regulation: the US experience (New ed). London: Verso.

Aglietta, M. (2010). La crise: le voies de sortie (Nouv. éd). Paris: Michalon.

Aiginger, K. (2015). Industrial Policy for a Sustainable Growth Path. In D. Bailey, K. Cowling, \& P. Tomlinson (Eds.), New Perspectives on Industrial Policy for a Modern Britain (pp. 364-394). Oxford University Press. https://doi.org/10.1093/acprof:oso/9780198706205.003.0019

Alonso, W. (1964). Location and Land Use: Toward a General Theory of Land Rent. 
Cambridge, Mass: Harvard University Press.

Amin, A. (2000). Industrial districts. In A Companion in Economic Geography. Oxford: Blackwell Publisher.

Antonelli, C. (2006). The Business Governance of Localized Knowledge: An Information Economics Approach for the Economics of Knowledge. Industry and Innovation, 13(3), 227-261. https://doi.org/10.1080/13662710600858118

Araujo, M. C., Ferreira, F. H. G., Lanjouw, P., \& Özler, B. (2008). Local inequality and project choice: Theory and evidence from Ecuador. Journal of Public Economics, 92(5-6), 1022-1046. https://doi.org/10.1016/j.jpubeco.2007.12.005

Armstrong, H. W., \& Taylor, J. (1993). Regional Economics \& Policy. Harvester Wheatsheaf. Asheim, B., \& Clark, E. (2001). Creativity and Cost in Urban and Regional Development in the "New Economy." European Planning Studies, 9(7), 805-811. https://doi.org/10.1080/09654310120079779

Asheim, B. T. (1996). Industrial districts as 'learning regions': A condition for prosperity. European Planning Studies, 4(4), 379-400. https://doi.org/10.1080/09654319608720354

Audretsch, D. B., \& Lehmann, E. E. (2005). Does the Knowledge Spillover Theory of Entrepreneurship hold for regions? Research Policy, 34(8), 1191-1202. https://doi.org/10.1016/j.respol.2005.03.012

Aydalot, P. (Ed.). (1984). Crise et espace. Paris: Economica.

Aydalot, P. (1986). Milieux innovateurs en Europe. Paris: GREMI.

Azariadis, C., Bullard, J., \& Ohanian, L. (2004). Trend-reverting fluctuations in the life-cycle model. Journal of Economic Theory, 119(2), 334-356. https://doi.org/10.1016/S0022-0531(03)00032-2

Baldwin, R. (1988). Factor Market Barriers are Trade Barriers: Gains from Trade in 1992 (Working Paper No. 2656). National Bureau of Economic Research. https://doi.org/10.3386/w2656

Balland, P.-A., Boschma, R., \& Frenken, K. (2015). Proximity and Innovation: From Statics to Dynamics. Regional Studies, 49(6), 907-920. https://doi.org/10.1080/00343404.2014.883598

Becattini, G. (1975). Lo sviluppo economico della Toscana: con particolare riguardo all'industrializzazione leggera. Firenze.

Becattini, G. (2002). From Marshall's to the Italian “Industrial Districts”. A Brief Critical Reconstruction. In A. Q. Curzio \& M. Fortis (Eds.), Complexity and Industrial Clusters (pp. 83-106). Physica-Verlag HD.

Belleflamme, P., Picard, P., \& Thisse, J.-F. (2000). An Economic Theory of Regional Clusters. Journal of Urban Economics, 48(1), 158-184. https://doi.org/10.1006/juec.1999.2161 
Benko, G., \& Lipietz, A. (Eds.). (2000). La richesse des régions: la nouvelle géographie socio-économique. Paris: Presses universitaires de France.

Best, M. H. (1990). The new competition: institutions of industrial restructuring. Cambridge, Mass: Harvard University Press.

Bhattacharya, A., Khanna, D., Schweizer, C., \& Bijapurkar, A. (2017, April 25). The New Globalization: Going Beyond the Rhetoric. Retrieved September 26, 2018, from https://www.bcg.com/en-gr/publications/2017/new-globalization-going-beyond-rhetoric.aspx

Boschma, R. (2005). Proximity and Innovation: A Critical Assessment. Regional Studies, 39(1), 61-74. https://doi.org/10.1080/0034340052000320887

Boschma, R. (2015). Towards an Evolutionary Perspective on Regional Resilience. Regional Studies, 49(5), 733-751. https://doi.org/10.1080/00343404.2014.959481

Boschma, R. A., \& Frenken, K. (2006). Why is economic geography not an evolutionary science? Towards an evolutionary economic geography. Journal of Economic Geography, 6(3), 273-302. https://doi.org/10.1093/jeg/lbi022

Boyer, R. (2004). Théorie de la régulation. 1: Les fondamentaux. Paris: La Découverte.

Briant, A., Combes, P.-P., \& Lafourcade, M. (2010). Dots to boxes: Do the size and shape of spatial units jeopardize economic geography estimations? Journal of Urban Economics, 67(3), 287-302. https://doi.org/10.1016/j.jue.2009.09.014

Brusco, S. (1982). The Emilian model: productive decentralisation and social integration. Cambridge Journal of Economics, 6(2), 167-184. https://doi.org/10.1093/oxfordjournals.cje.a035506

Camagni, R. P. (1995). The Concept of Innovative Milieu and Its Relevance for Public Policies in European Lagging Regions. Papers in Regional Science, 74(4), 317-340. https://doi.org/10.1111/j.1435-5597.1995.tb00644.x

Cameron, R. (1970). Europe's Second Logistic. Comparative Studies in Society and History, $12(4), 452-462$.

Carlino, G., \& Kerr, W. R. (2014). Agglomeration and Innovation (Working Paper No. 20367). National Bureau of Economic Research. https://doi.org/10.3386/w20367

Chinitz, B. (1966). Appropriate Goals for Regional Economic Policy. Urban Studies, 3(1), 1-7. https://doi.org/10.1080/00420986620080011

Chipman, J. S., \& Winker, P. (1992). Optimal aggregation by threshold accepting: An application to the German industrial classification system (Working Paper No. 180). Diskussionsbeiträge: Serie II, Sonderforschungsbereich 178 "Internationalisierung der Wirtschaft", Universität Konstanz. Retrieved from https://www.econstor.eu/handle/10419/101634

Chisholm, M. (1990). Regions in recession and resurgence. London: Unwin Hyman. 
Clark, C. (1967). Von Thunen's Isolated State. Oxford Economic Papers, 19(3), 370-377.

Cohen, M. D., March, J. G., \& Olsen, J. P. (1972). A Garbage Can Model of Organizational Choice. Administrative Science Quarterly, 17(1), 1-25. https://doi.org/10.2307/2392088

Cohen, W. M., \& Levinthal, D. A. (1989). Innovation and Learning: The Two Faces of R \& D. The Economic Journal, 99(397), 569-596. https://doi.org/10.2307/2233763

Coleman, J. S. (1988). Social Capital in the Creation of Human Capital. American Journal of Sociology, 94, S95-S120.

Cooke, Phil. (2007). Social capital, embeddedness, and market interactions: An analysis of firm performance in UK regions. Review of Social Economy, 65(1), 79-106. https://doi.org/10.1080/00346760601132170

Cooke, Philip, Gomez Uranga, M., \& Etxebarria, G. (1997). Regional innovation systems: Institutional and organisational dimensions. Research Policy, 26(4-5), 475-491.

Cooke, Philip, \& Wills, D. (1999). Small Firms, Social Capital and the Enhancement of Business Performance Through Innovation Programmes. Small Business Economics, 13(3), 219-234. https://doi.org/10.1023/A:1008178808631

Courlet, C. (2008). L'économie territoriale. Saint-Martin-d'Hères (Isère): Pug.

Cox, K. R. (1998). Spaces of dependence, spaces of engagement and the politics of scale, or: looking for local politics. Political Geography, 17(1), 1-23. https://doi.org/10.1016/S0962-6298(97)00048-6

Crespo, J., Suire, R., \& Vicente, J. (2014). Lock-in or lock-out? How structural properties of knowledge networks affect regional resilience. Journal of Economic Geography, 14(1), 199-219. https://doi.org/10.1093/jeg/lbt006

Cumming, G., Cumming, D. H. M., \& Redman, C. (2006). Scale Mismatches in Social-Ecological Systems: Causes, Consequences, and Solutions. Ecology and Society, 11(1). https://doi.org/10.5751/ES-01569-110114

Cyert, R. M., \& March, J. G. (1963). A Behavioral Theory of the Firm. New Jersey: Prentice Hall.

Dakhli, M., \& De Clercq, D. (2004). Human capital, social capital, and innovation: a multi-country study. Entrepreneurship \& Regional Development, 16(2), 107-128.

David, P. (1985). Clio and the Economics of QWERTY. American Economic Review, 75(2), $332-337$.

Davis, D. R., \& Weinstein, D. E. (1996). Does Economic Geography Matter for International Specialization? (Working Paper No. 5706). National Bureau of Economic Research. https://doi.org/10.3386/w5706

Deardorff, A. V. (1995). Determinants of Bilateral Trade: Does Gravity Work in a Neoclassical World? (NBER Working Papers No. 5377). National Bureau of Economic 
Research, Inc. Retrieved from https://ideas.repec.org/p/nbr/nberwo/5377.html

Deardorff, A. V. (2004). Trade and location: A moving example motivated by Japan (Hi-Stat Discussion Paper Series No. d04-56). Institute of Economic Research, Hitotsubashi University. Retrieved from https://ideas.repec.org/p/hst/hstdps/d04-56.html

Deardorff, A. V. (2005). Ricardian comparative advantage with intermediate inputs. The North American Journal of Economics and Finance, 16(1), 11-34. https://doi.org/10.1016/j.najef.2004.11.003

Debaere, P. (1998). "Endowments Do Matter" Relative Factor Abundance and Trade (Working Papers No. 429). Research Seminar in International Economics, University of Michigan. Retrieved from https://ideas.repec.org/p/mie/wpaper/429.html

Dosi, G. (2016). Beyond the 'magic of the market'. The slow return of industrial policy (but not yet in Italy). Economia e Politica Industriale, 43(3), 261-264. https://doi.org/10.1007/s40812-016-0041-x

Dunn, E. S. (1954). The location of agricultural production. Gainesville, Fla.: University of Florida Press. Retrieved from https://trove.nla.gov.au/version/23950100

Faggian, A., \& McCann, P. (2009). Human capital, graduate migration and innovation in British regions. Cambridge Journal of Economics, 33(2), 317-333.

Filho, N. M., \& Scorzafave, L. (2001). Employment and Inequality Outcomes in Brazil (p. 36). OECD.

Fingleton, B. (2001). Theoretical economic geography and spatial econometrics: dynamic perspectives. Journal of Economic Geography, 1(2), 201-225. https://doi.org/10.1093/jeg/1.2.201

Fingleton, B., \& López-Bazo, E. (2006). Empirical growth models with spatial effects*. Papers in Regional Science, 85(2), 177-198. https://doi.org/10.1111/j.1435-5957.2006.00074.x

Florida, R. (1996a). Lean and Green: The Move to Environmentally Conscious Manufacturing. California Management Review, 39(1), 80-105. https://doi.org/10.2307/41165877

Florida, R. (1996b). Regional Creative Destruction: Production Organization, Globalization, and the Economic Transformation of the Midwest. Economic Geography, 72(3), 314-334. https://doi.org/10.2307/144403

Frank, André Gunder. (1967). Capitalism and underdevelopment in Latin America: historical studies of Chile and Brazil. New Tork: Monthly Review Press.

Frank, Andre Gunder. (1976). Economic Genocide in Chile: Open Letter to Milton Friedman and Arnold Harberger. Economic and Political Weekly, 11(24), 880-888.

Friedman, D. (1998a). Evolutionary economics goes mainstream: A review of the theory of 
learning in games. Journal of Evolutionary Economics, 8(4), 423-432. https://doi.org/10.1007/s001910050071

Friedman, D. (1998b). On economic applications of evolutionary game theory. Journal of Evolutionary Economics, 8(1), 15-43. https://doi.org/10.1007/s001910050054

Fujita, M., \& Krugman, P. (1995). When is the economy monocentric?: von Thünen and Chamberlin unified. Regional Science and Urban Economics, 25(4), 505-528. https://doi.org/10.1016/0166-0462(95)02098-F

Fujita, M., Krugman, P. R., \& Venables, A. (1999). The spatial economy: cities, regions and international trade. Cambridge, Mass: MIT Press.

Galbraith, J. K. (2007). The New Industrial State (1st Princeton Ed edition (first published in 1967)). Princeton, N.J: Princeton University Press.

Gilpin, R., \& Gilpin, J. M. (2001). Global political economy: understanding the international economic order. Princeton, N.J: Princeton University Press.

Gordon, I. R., \& McCann, P. (2000). Industrial Clusters: Complexes, Agglomeration and/or Social Networks? Urban Studies, 37(3), 513-532. https://doi.org/10.1080/0042098002096

Guillén, M. F. (2001). The Limits of Convergence: Globalization and Organizational Change in Argentina, South Korea, and Spain. Princeton University Press. Retrieved from https://www.jstor.org/stable/j.ctt7scd0

Hadjimichalis, C. (2011). Uneven geographical development and socio-spatial justice and solidarity: European regions after the 2009 financial crisis. European Urban and Regional Studies, 18(3), 254-274. https://doi.org/10.1177/0969776411404873

Hadjimichalis, C., \& Hudson, R. (2006). Networks, Regional Development and Democratic Control. International Journal of Urban and Regional Research, 30(4), 858-872. https://doi.org/10.1111/j.1468-2427.2006.00687.x

Hadjimichalis, C., \& Hudson, R. (2014). Contemporary Crisis Across Europe and the Crisis of Regional Development Theories. Regional Studies, 48(1), 208-218. https://doi.org/10.1080/00343404.2013.834044

Hall, B. H. (2004). Innovation and Diffusion (Working Paper No. 10212). National Bureau of Economic Research. https://doi.org/10.3386/w10212

Hannon, B. (1997). The use of analogy in biology and economics: From biology to economics, and back. Structural Change and Economic Dynamics, 8(4), 471-488. https://doi.org/10.1016/S0954-349X(97)00019-2

Harle, V., Moisio, S., \& Aalto, P. (2016). Global and Regional Problems: Towards an Interdisciplinary Study. London: Taylor \& Francis. Retrieved from http://public.eblib.com/choice/publicfullrecord.aspx?p=4512760

Harvey, D. (2006). The limits to capital (New and fully updated edition). London ; New York: 
Verso.

Healey, M., \& Ilbery, B. W. (1990). Location and change: perspectives on economic geography. Oxford; New York: Oxford University Press. Retrieved from https://trove.nla.gov.au/version/6537441

Henderson, J. V., \& Thisse, J.-F. (Eds.). (2008). Cities and geography (1. ed., Repr). Amsterdam: Elsevier.

Hodgson, G. M. (1999). Economics and evolution: bringing life back into economics. Ann Arbor (Mich.): University of Michigan Press.

Holland, S. (1976). Capital versus the regions. London: Macmillan.

Iansiti, M., \& Levien, R. (2004). The keystone advantage: what the new dynamics of business ecosystems mean for strategy, innovation, and sustainability. Boston, Mass: Harvard Business School Press.

Jacobs, J. (1961). The Death and Life of Great American Cities. New York: Random House.

Kaldor, N. (1970). The Case for Regional Policies*. Scottish Journal of Political Economy, 17(3), 337-348. https://doi.org/10.1111/j.1467-9485.1970.tb00712.x

Kaldor, N., Targetti, F., \& Thirlwall, A. P. (1989). Further essays on economic theory and policy. London : Duckworth. Retrieved from https://trove.nla.gov.au/work/16590851

Kaufmann, A., \& Tödtling, F. (2001). Science-industry interaction in the process of innovation: the importance of boundary-crossing between systems. Research Policy, 30(5), 791-804.

Knox, P., Agnew, J., \& McCarthy, L. (2008). The Geography of the World Economy (5th ed). London : Hodder Education. Retrieved from https://trove.nla.gov.au/work/17947744

Kondratieff, N. D., \& Stolper, W. F. (1935). The Long Waves in Economic Life. The Review of Economics and Statistics, 17(6), 105-115. https://doi.org/10.2307/1928486

Kotz, D. M. (2003). Neoliberalism and the Social Structure of Accumulation Theory of Long-Run Capital Accumulation. Review of Radical Political Economics, 35(3), 263-270. https://doi.org/10.1177/0486613403255542

Krugman, P. (1980). Scale Economies, Product Differentiation, and the Pattern of Trade. The American Economic Review, 70(5), 950-959.

Krugman, P. (1991). Increasing Returns and Economic Geography. Journal of Political Economy, 99(3), 483-499. https://doi.org/10.1086/261763

Krugman, P. R. (1985). Increasing Returns and the Theory of International Trade (Working Paper No. 1752). National Bureau of Economic Research. https://doi.org/10.3386/w1752

Krugman, P. R., Obstfeld, M., \& Melitz, M. J. (2018). International economics: theory \& policy (Eleventh Edition). New York: Pearson. 
Kuhn, T. S. (1963). The Function of Dogma in Scientific Research. In Scientific Change (Symposium on the History of Science, University of Oxford, 9-15 July 1961) (pp. 347-369). New York; London: Basic Books and Heineman.

Kuhn, T. S. (1977). The essential tension: selected studies in scientific tradition and change. Chicago: University of Chicago Press.

Kuhn, T. S. (1996). The structure of scientific revolutions (3rd ed (Originally published: 1962)). Chicago, IL: University of Chicago Press.

Kuznets, S. (1973). Modern Economic Growth: Findings and Reflections. The American Economic Review, 63(3), 247-258.

Kuznets, S. (1980). Driving forces of economic growth: What can we learn from history? Review of World Economics, 116(3), 409-431. https://doi.org/10.1007/BF02708815

Laudicina, P. A., \& Peterson, E. R. (2016). From Globalization to Islandization (Global Business Policy Council (GBPC) /Research Report) (p. 26). ATKearney. Retrieved from https://www.atkearney.com/web/global-business-policy-council/article?/a/from-globalizationto-islandization

Launhardt, W. (1882). Die Bestimmung des zweckmässigsten Standortes einer gewerblichen Anlage. Zeitschrift Des Vereines Deutscher Ingenieure, 26, 106-115.

Laursen, K., \& Meliciani, V. (2000). The Importance of Technology-Based Intersectoral Linkages for Market Share Dynamics. Weltwirtschaftliches Archiv, 136(4), 702-723.

Lazzeretti, L., Sedita, S. R., \& Caloffi, A. (2014). Founders and disseminators of cluster research. Journal of Economic Geography, 14(1), 21-43. https://doi.org/10.1093/jeg/lbs053

Lee, E., \& Vivarelli, M. (2006). The social impact of globalization in the developing countries. International Labour Review, 145(3), 167-184. https://doi.org/10.1111/j.1564-913X.2006.tb00016.x

Lewin, R. (2000). Complexity: Life at the Edge of Chaos (2nd edition). Chicago, Ill: University of Chicago Press.

Lipietz, A. (1986). New Tendencies in the International Division of Labour: Regimes of Accumulation and Modes of Regulation. In Production, Work, and Territory: The Geographical Anatomy of Industrial Capitalism (pp. 16-40). Boston: Allen and Unwin.

Lösch, A. (1954). Economics of location. New Haven,: Yale University Press (Originally published in 1939). Retrieved from http://archive.org/details/economicsoflocat001s

Malecki, E. J. (1983). Technology and Regional Development: A Survey. International Regional Science Review, 8(2), 89-125. https://doi.org/10.1177/016001768300800201

Markusen, A. R. (1985). Profit cycles, oligopoly, and regional development. Cambridge, Mass: MIT Press.

Marshall, A. (1879). The Pure Theory of (Domestic) Values (History of Economic Thought 
Books). McMaster University Archive for the History of Economic Thought. Retrieved from https://econpapers.repec.org/bookchap/hayhetboo/marshall1879a.htm

Marshall, A. (1919). Industry and Trade: A Study of Industrial Technique and Business Organization and of Their Influences on the Condition of Various Classes and Nations. London; New York: MacMillian and Co. Limited.

Marshall, A. (1920). Principles of Economics (8th Edition). London: Macmillan.

Martin, R. (2008). Institutional Approaches in Economic Geography. In A Companion to Economic Geography (pp. 77-94). Wiley-Blackwell. https://doi.org/10.1002/9780470693445.ch6

Martin, R. (2009). Roepke Lecture in Economic Geography-Rethinking Regional Path Dependence: Beyond Lock-in to Evolution: ECONOMIC GEOGRAPHY. Economic Geography, 86(1), 1-27. https://doi.org/10.1111/j.1944-8287.2009.01056.x

Maskell, P., \& Malmberg, A. (1999). Localised Learning and Industrial Competitiveness. Cambridge Journal of Economics, 23(2), 167-185.

Maurseth, P. B. (2003). Economic Convergence through Savings, Trade and Technology Flows: Lessons from Recent Research. Forum for Development Studies, 30(1), 29-58. https://doi.org/10.1080/08039410.2003.9666229

McCann, P., \& Ortega-Argilés, R. (2013). Modern regional innovation policy. Cambridge Journal of Regions, Economy and Society, 6(2), 187-216. https://doi.org/10.1093/cjres/rst007

Mcdonough, T. (1995). Lenin, Imperialism, and the Stages of Capitalist Development. Science \& Society, 59(3), 339-367.

McDonough, T. (2007). The Marxian Theory of Capitalist Stages. In Transitions in Latin America and in Poland and Syria (Vol. 24, pp. 241-280). Emerald Group Publishing Limited. https://doi.org/10.1016/S0161-7230(07)24007-6

Metcalfe, J. S., \& Soete, L. (1984). Notes on the evolution of technology and international competition. In Science and Technology Policy in the 1980's and Beyond. London: Longman.

Moore, J. (1993). Predators and prey: a new ecology of competition. Harvard Business Review, 71(3), 75-86.

Morgan, K. (1997). The Learning Region: Institutions, Innovation and Regional Renewal. Regional Studies, 31(5), 491-503. https://doi.org/10.1080/00343409750132289

Muller, E. (2001). Knowledge, Innovation Processes and Regions. In K. Koschatzky, M. Kulicke, \& A. Zenker (Eds.), Innovation Networks (pp. 37-51). Physica-Verlag HD.

Newman, B. J., Johnston, C. D., \& Lown, P. L. (2015). False Consciousness or Class Awareness? Local Income Inequality, Personal Economic Position, and Belief in American Meritocracy. American Journal of Political Science, 59(2), 326-340. https://doi.org/10.1111/ajps.12153 
Nonaka, I., \& Takeuchi, H. (1995). The knowledge-creating company: how Japanese companies create the dynamics of innovation. New York: Oxford University Press.

North, D. C. (1990). Institutions, institutional change, and economic performance. Cambridge ; New York: Cambridge University Press.

OECD. (2009). Investing for Growth: Building Innovative Regions (Conclusions of the meeting of the territorial development policy committee (TDPC) at ministerial level). Paris. Retrieved from http://www.oecd.org/cfe/regional-policy/TDPC\%202009\%20Ministerial\%20Conclusions.pdf

Ohlin, B. G. (1933). Interregional and international trade, by Bertil Ohlin. Cambridge: Harvard University Press.

Olson, M. (2003). The logic of collective action: public goods and the theory of groups (21. printing (Publication: January 1971)). Cambridge, Mass.: Harvard Univ. Press.

Palander, T. (1935). Beitrage Zur Standurts theories. In Industrial Location (pp. 75-93). New York: John Wiley (1981).

Peneder, M. (2016). Competitiveness and industrial policy: from rationalities of failure towards the ability to evolve. Cambridge Journal of Economics, 829-858. https://doi.org/10.1093/cje/bew025

Perrons, D. C. (1981). The role of Ireland in the new international division of labour: A proposed framework for regional analysis. Regional Studies, 15(2), 81-100. https://doi.org/10.1080/09595238100185111

Pfaffermayr, M. (2007). Conditional Beta- and Sigma-Convergence in Space: A Maximum-Likelihood Approach (SSRN Scholarly Paper No. ID 1013297). Rochester, NY: Social Science Research Network. Retrieved from https://papers.ssrn.com/abstract=1013297

Pike, A., Rodríguez-Pose, A., \& Tomaney, J. (2006). Local and regional development. London : New York: Routledge, Taylor \& Francis Group.

Pike, A., Rodríguez-Pose, A., \& Tomaney, J. (2007). What Kind of Local and Regional Development and for Whom? Regional Studies, 41(9), 1253-1269. https://doi.org/10.1080/00343400701543355

Polanyi, K. (2001). The Great Transformation: The Political and Economic Origins of Our Time (2 edition (first UK edition 1945)). Boston, MA: Beacon Press.

Porter, M. (1990). The competitive advantage of nations. New York: Free Press.

Porter, M. (2000). Location, Competition, and Economic Development: Local Clusters in a Global Economy. Economic Development Quarterly, 14(1), 15-34. https://doi.org/10.1177/089124240001400105

Portes, A. (1998). Social Capital: Its Origins and Applications in Modern Sociology. Annual Review of Sociology, 24(1), 1-24. https://doi.org/10.1146/annurev.soc.24.1.1 
Posner, M. V. (1961). International Trade and Technical Change. Oxford Economic Papers, 13(3), 323-341.

Putnam, R. (1993). The Prosperous Community: Social Capital and Public Life. The American Prospect, (13), 35-42.

Reuveny, R., \& Thompson, W. R. (2001). Leading Sectors, Lead Economies, and Economic Growth. Review of International Political Economy, 8(4), 689-719.

Ricardo, D. (1817). On the Principles of Political Economy and Taxation. London: J. Murray.

Rinkinen, S., \& Harmaakorpi, V. (2018). The business ecosystem concept in innovation policy context: building a conceptual framework. Innovation: The European Journal of Social Science Research, 31(3), 333-349. https://doi.org/10.1080/13511610.2017.1300089

Rivera-Batiz, L. A., \& Romer, P. M. (1991). International Trade with Endogenous Technological Change (Working Paper No. 3594). National Bureau of Economic Research. https://doi.org/10.3386/w3594

Rodrik, D. (2011). The globalization paradox: why global markets, states, and democracy can't coexist. Oxford; New York: Oxford University Press.

Rostow, W. W. (1952). The process of economic growth. New York: Norton. Retrieved from http://catalog.hathitrust.org/api/volumes/oclc/2691612.html

Rostow, W. W. (1956). The Take-Off Into Self-Sustained Growth. The Economic Journal, 66(261), 25-48. https://doi.org/10.2307/2227401

Rostow, W. W. (1959). The Stages of Economic Growth. The Economic History Review, 12(1), 1-16. https://doi.org/10.2307/2591077

Rostow, W. W. (1960). The stages of economic growth: A non-communist manifesto. Cambridge: Cambridge University Press.

Rostow, W. W. (1963). Leading Sectors and the Take-off. In W. W. Rostow (Ed.), The Economics of Take-Off into Sustained Growth (pp. 1-21). London: Palgrave Macmillan UK. https://doi.org/10.1007/978-1-349-63959-5_1

Rothschild, M. (1990). Bionomics: the inevitability of capitalism (1st ed). New York: H. Holt.

Samuelson, P. A. (1948). International Trade and the Equalisation of Factor Prices. The Economic Journal, 58(230), 163-184. https://doi.org/10.2307/2225933

Samuelson, P. A. (1949). International Factor-Price Equalisation Once Again. The Economic Journal, 59(234), 181-197. https://doi.org/10.2307/2226683

Santos, M. (1977). Spatial Dialectics: The Two Circuits of Urban Economy in Underdeveloped Countries. Antipode, 49-60. https://doi.org/10.1111/j.1467-8330.1977.tb00092.x

Sapir, J. (2011). La démondialisation. Paris: Seuil. 
Saxenian, A. (1990). Regional Networks and the Resurgence of Silicon Valley. California Management Review, 33(1), 89-112. https://doi.org/10.2307/41166640

Saxenian, A. (1994). Regional advantage: culture and competition in Silicon Valley and Route 128. Cambridge, Mass: Harvard University Press.

Sayer, R. A. (1992). Method in social science: a realist approach (2nd ed). London; New York: Routledge.

Schumpeter, J. (1934). The theory of economic development; an inquiry into profits, capital, credit, interest, and the business cycle. Cambridge, Mass.: Harvard University Press.

Schumpeter, J. (1939). Business cycles: a theoretical, historical, and statistical analysis of the capitalist process. New York: McGraw-Hill.

Scott, A. (1988). New industrial spaces: Flexible production organization and regional development in North America and Western Europe. London: Pion.

Simon, H. A. (1947). Administrative Behavior: a Study of Decision-Making Processes in Administrative Organization. New York: Macmillan.

Simon, H. A. (1955). A Behavioral Model of Rational Choice. The Quarterly Journal of Economics, 69(1), 99-118. https://doi.org/10.2307/1884852

Simon, H. A. (1973). Applying Information Technology to Organization Design. Public Administration Review, 33(3), 268-278. https://doi.org/10.2307/974804

Simon, H. A. (1996). The sciences of the artificial (Third Edition). Cambridge, Mass.: MIT Press. Retrieved from http://ieeexplore.ieee.org/servlet/opac?bknumber=6267338

Skinner, A. (1988). Adam Smith and economic liberalism. Edinburgh: David Hume Institute.

Smith, A. (1776). An Inquiry into the Nature and Causes of the Wealth of Nations. London: Strahan and Cadell.

Storper, M. (1991). Industrialization, economic development and the regional question in the Third World: from import substitution to flexible production. London: Pion.

Storper, M., \& Christopherson, S. (1987). Flexible Specialization and Regional Industrial Agglomerations: The Case of the U.S. Motion Picture Industry. Annals of the Association of American Geographers, 77(1), 104-117. https://doi.org/10.1111/j.1467-8306.1987.tb00148.x

Thirlwall, A. P. (2006). Growth and development: with special reference to developing economies (8th ed). Houndmills, Basingstoke, Hampshire; New York, N.Y.: Palgrave Macmillan. Retrieved from https://trove.nla.gov.au/work/2169545

Thünen, V. (1826). Der Isolierte Staat in Beziehung auf Landwirtschaf und Nationalokonomie.

Tomaskovic-Devey, D., \& Roscigno, V. J. (1997). Uneven Development and Local Inequality in the U.S. South: The Role of Outside Investment, Landed Elites, and Racial Dynamics. 
Sociological Forum, 12(4), 565-597. https://doi.org/10.1023/A:1022174707289

Townroe, P. M. (1983). United Kingdom. In Industrial mobility and migration in the European Community. Aldershot: Gower.

Veblen, T. (1898). Why is Economics not an Evolutionary Science? The Quarterly Journal of Economics, 12(4), 373-397. https://doi.org/10.2307/1882952

Verdoorn, P. J. (1980). Verdoorn's Law in Retrospect: A Comment. The Economic Journal, 90(358), 382-385. https://doi.org/10.2307/2231798

Vines, D. (1987). Macroeconomic policy after monetarism: a summary. Royal Bank of Scotland Quarterly Review ; 1986.

Vivarelli, M. (2004). Globalization, Skills and Within-Country Income Inequality in Developing Countries. In Understanding Globalization, Employment and Poverty Reduction (pp. 211-243). New York: Palgrave Macmillan.

Vlados, C. (2004). La dynamique du triangle stratégie, technologie et management: l'insertion des entreprises grecques dans la globalisation. Paris 10. Retrieved from http://www.theses.fr/2004PA100022

Vlados, C. (2005). The insertion of Greek firms into globalization: The dynamics of the triangle of strategy, technology and management. Presented at the Managing Global Trends and Challenges in a Turbulent Economy, University of the Aegean, Department of Business Administration.

Vlados, C. (2012). The search of competitiveness and the entrepreneurial evolution in a global environment: Toward a new approach of development dynamics based on the case of Greek productive system. Journal of Management Sciences and Regional Development, (8), 91-116.

Vlados, C., Deniozos, N., \& Chatzinikolaou, D. (2018a). Global Crisis, Innovation and Change Management: Towards a New Systemic Perception of the Current Globalization Restructuring. International Business Research, 11(8), 9-29. https://doi.org/10.5539/ibr.v11n8p9

Vlados, C., Deniozos, N., \& Chatzinikolaou, D. (2018b). The "evil globalization" \& the central dialectic tug-of-war in the new globalization's shaping. Civitas Gentium, 6(1), 89-134.

Vlados, C., Deniozos, N., Chatzinikolaou, D., \& Demertzis, M. (2018a). Perceiving Competitiveness under the Restructuring Process of Globalization. International Journal of Business and Management, 13(8), 135-153. https://doi.org/10.5539/ijbm.v13n8p135

Vlados, C., Deniozos, N., Chatzinikolaou, D., \& Demertzis, M. (2018b). Towards an Evolutionary Understanding of the Current Global Socio-economic Crisis and Restructuring: From a Conjunctural to a Structural and Evolutionary Perspective. Research in World Economy, 9(1), 15-33. https://doi.org/10.5430/rwe.v9n1p15 
Weber, A. (1909). Uber den Standort der Industrien.

Weber, A. (1929). The Theory of the Location of Industries. Chicago: University of Chicago Press.

Weick, K. E. (1993). The Collapse of Sensemaking in Organizations: The Mann Gulch Disaster. Administrative Science Quarterly, 38(4), 628-652. https://doi.org/10.2307/2393339

Williamson, O. E. (1985). The Economic Institutions of Capitalism: Firms, Markets, Relational Contracting. Free Press.

Wingo, L. (1961). An Economic Model of the Utilization of Urban Land. Papers in Regional Science, 7(1), 191-205. https://doi.org/10.1111/j.1435-5597.1961.tb01779.x

Witt, U. (2008). What is specific about evolutionary economics? Journal of Evolutionary Economics, 18(5), 547-575. https://doi.org/10.1007/s00191-008-0107-7

World Commission on Environment and Development (Ed.). (1987). Our common future. Oxford ; New York: Oxford University Press.

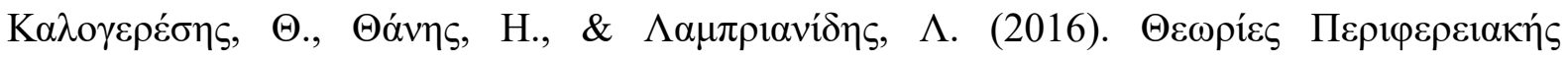

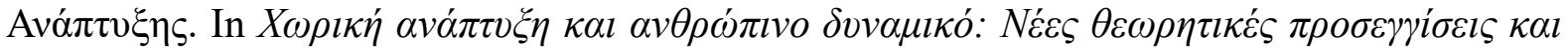

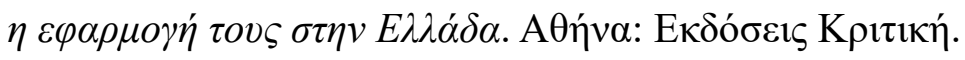

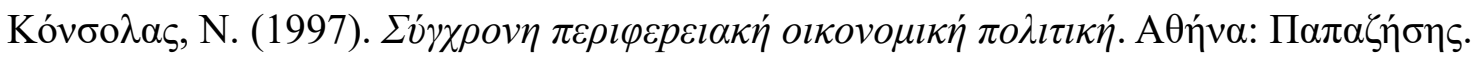

\section{Notes}

Note 1. For the basis of this theoretical framework see specifically the works of Bertil Ohlin (Ohlin, 1933), of Paul Samuelson (Samuelson, 1949), who influenced greatly the neoclassical approach, and the classic work of Krugman and Obstfeld (Krugman, Obstfeld, \& Melitz, 2018).

Note 2. Generally, Verdoorn Law supports that in the long run productivity grows proportionally to the square root of output.

\section{Copyright Disclaimer}

Copyright for this article is retained by the author(s), with first publication rights granted to the journal.

This is an open-access article distributed under the terms and conditions of the Creative Commons Attribution license (http://creativecommons.org/licenses/by/3.0/). 